\title{
Kırsal Mirasın Sürekliliği Üzerine Bir İnceleme: Göynük Hisarözü Köyü Örneği
}

\author{
Derya Gümüş \\ Kocaeli Üniversitesi
}

\author{
Emre Kishalı \\ Kocaeli Üniversitesi
}

\section{Öz}

Kırsal mirasın sürdürülebilirliği açısından araştırma alanı olarak Bolu İli, Göynük İlçesi'ne bağlı Hisarözü Köyü seçilmiştir. Köy ile ilgili literatür taraması yapılmış ancak yeterli veri bulunamamıştır. Bu kapsamda, mevcut dokuda yer alan yapılar üzerinde gözlem ve fotoğraflama çalışmaları, köyde yaşayan kişilerle sözlü görüşmeler, alana ait analiz çalışmaları yapılmıştır. Hisarözü Köyü, kırsal özelliklerini hiç yitirmemiş ve mimari miras özgün karakterini büyük oranda korumuştur. Alan incelemesi yapıldığında yerleşik nüfusun çok az sayıda olduğu, konut yapılarının strüktürel bağlamda să̆lamlı̆̆ın koruduğu fakat sosyo-ekonomik etkenlerden dolayı başka yere göç, hissedarlık durumları, yakıttan tasarruf etme amacı gibi nedenlerle çoğunun kullanılmadı̆̆ gözlenmişstir. Ambar yapılarının tamamen kullanım dışı kaldı̆̆ı, samanlı yapılarının bazılarının ise hayvancllkla uğraşan köy halknnın kullanmaya devam ettikleri görülmektedir. Çalışma 4 aşamadan oluşmaktadır. Birinci bölümde kırsal mimarlk, miras ve korumadan bahsedilmiştir. İkinci bölümde kent-kır kavramı arasinda kalan Göynük Illçesi'nin ve bu ilçeye bağh olan Hisarözü Köyü'nün tarihsel gelişimi, fiziksel, sosyal, ekonomik özellikleri ve kursal mimarisi açıllanmaktadir. Üçüncü bölümde kirsal miras olarak belgelendirebileceğimiz Hisarözü Köyü'nün koruma ve sürdürülebilirlik sorunlarnna değinilmiştir. Son bölümde ise kırsal mirasın korunması ve sürdürülebilirliği üzerine önerilerde bulunulmuştur.

Anahtar Kelimeler: Göynük, Hisarözü, Sürdürülebilirlik, Kırsal Miras

idealkent @ Kent Araştırmaları Dergisi (Journal of Urban Studies)

http://idealkentdergisi.com

Geliş Tarihi Received Date: 16.11.2018 Kabul Tarihi Accepted Date: 30.12.2018 


\title{
A Research on the Continuity of Rural Heritage: The Case of Hisarözü Village
}

\author{
Derya Gümüş \\ Kocaeli University
}

\author{
Emre Kishalı \\ Kocaeli University
}

\begin{abstract}
The village of Hisarözü in Göynük town of Bolu Province was selected as a case study in the context of the sustainability of rural heritage. The literature review was conducted for the area; however, insufficient data was reached. Therefore, direct investigation and photography on the existing buildings in the urban fabric, interviews with the inhabitants and the analysis of rural areas were carried out during the field visits. Rural properties of the village were not lost and the original character of architecture heritage substantially preserved. When the field study was finished, it is observed that the number of inhabitants is few, the structural safety of the building is good but most of them are obsolete due to the socio-cultural effects such as migration to larger settlements, multi shareholdings, and energy saving issues. Moreover, it is deduced that all storehouse buildings are vacant whereas the some of the haylofts are still being used by the inhabitants working on the husbandry. In the research there are four phases in the methodology. In the first part, the rural architecture, heritage, and conservation were discussed. In the second part, the historical development, physical, social, economic properties and rural architecture of Göynük which is retained between the urban-rural interface and of the Hisarözü Village were elucidated. Later, the conservation and sustainability problems of the rural architecture in the village were addressed. Finally, the suggestions on conserving and sustaining the rural architecture were suggested.
\end{abstract}

Keywords: Göynük, Hisarözü, Sustainability, Rural Heritage 


\section{Giriş}

Kırsal ve kentsel yerleşimlerin arasındaki farklılık, genellikle idari statü, yerleşme büyüklüğü, yapısal gelişmişlik gibi ölçütlerle nitelendirilmiştir (Soysal, 1998). Dünya Vernaküler Mimarlık Ansiklopedisi'nde kırsal mimarlığın tanımı; "[...] halk tarafından yapılmış tüm evler ve diğer yapıları kapsar. Seçilen çevrenin olanakları ve elde var olan malzemelerle, çoğunlukla konut sahibi ya da yerel yapı ustaları tarafından geleneksel tekniklerle inşa edilmiştir. Halk mimarlığının tüm formları belirli gereksinimleri karşılamaya yöneliktir; bu gereksinimlerin ardındaki kültürün, yaşam tarzının, ekonomik faaliyetin ve değerlerin izlerini taşır." (Oliver, 1998) şeklinde yapılmıştır. Aran ise 'kırsal mimarlık'ı tanımlayan diğer kavramlara, Barınaktan Öte: Anadolu Kır Yapıları adlı çalışmasında 'halk mimarlığı', 'yöresel/yerel mimarlık', ‘vernaküler mimari', 'spontan mimarlık', 'Tarım Çağ1 mimarlığı' şeklinde değinmiştir (Aran, 2000).

$\mathrm{Bu}$ tanımlardan sonra, 18. yüzyılın ikinci yarısında başlayan Sanayi Devrimi'nin kırsal ve kentsel alanlara olan etkisi de tartışılmalıdır. Cengiz Bektaş, Osmanlı dönemine dair yaptığı araştırmalar sonucunda, Sanayi Devrimi'ne kadar olan Anadolu kırsal mimarlığının temel ilkelerini oluşturmuştur (Bektaş, 2001). Bu ilkeler, çevre koşullarına uyum, çözümün akılcı olması, ölçülerin insan bedeni temel alınarak oluşturulması, iklime uygunluk, yerel malzemelerin kullanılması gibi kavramlardan oluşmaktadır. Sanayi Devrimi'nin bir sonucu olarak tarımda makineleşmeye gidilmesiyle kırsal alanlarda iş gücü ihtiyacı azalmış, halk burayı terk etmeye başlamıştır (Eres, 2013). Bununla beraber kentlerde fabrikaların artmasıyla da nüfus bu alanlara yoğunlaşmış ve düzensiz bir kentleşmeye doğru gidilmiştir.

Uluslararası literatürde, kırsal alan üzerine irdelemeler ve bu alanların sürekliliği üzerine tartışmalar kapsamlı olarak devam etmektedir (Brower, 1988, 1989; Oliver, 1997, 2002; Rapoport, 2002; Scazzosi, 2018). Brower'a göre kişisel beğeniler doğrultusunda koruma isteği, köyde yaşayan halkı içine katmadan sadece dişardakilerin değerlendirmelerine dayanır (Brower, 1988, 1989; Rapoport, 2002). Öte yandan, sosyal yapılar ve işlevsel durum karşısında şekillenen kırsal miras alanları, kültürel ve doğal özellikleri de barındırır. Kültürel miras farklı dönemleri kapsayarak hem modern hem de geleneksel olarak okunmaktadır (ICOMOS, 2017). Scazzosi'ye göre; fiziksel nesne olarak değerlendirilen kırsal peyzaj, beş 
duyu (görme, duyma, koku, his ve tat) araciyla insanlar tarafından algılanır. Bu kırsal peyzaj doğal ve üretilmiş malzemelerle inşa edilmiştir ve her zaman dinamiktir (Scazzosi, 2018). Kırsal alanda inşa edilen mimarsız yapıların yerel malzemeler kullanılarak biçimsel çeşitlilik içinde üretilmesi, kültürün sosyal ve çevresel ihtiyaçlarla beraber hareket etmesi sonucundadır (Oliver, 1997, 2002). Bunun sonucunda miras olarak nitelenen kırsal peyzajlar, geçmişte ve günümüzde, bunları gerçekleştiren, kullanan ve dönüştüren sosyal yapılar ve işlevsel örgütlerin ifadeleridir. Biyo-kültürel çeşitliliğin devam etmesine katkıda bulunan kültürel, manevi ve doğal özellikleri kapsar. Tüm kırsal alanlar, hem modern, hem de sıradan, geleneksel ve son zamanlarda modernizasyon faaliyetleri tarafından dönüştürülmüş miras olarak okunur.

Bu bilgiler doğrultusunda Hisarözü Köyü'nün kırsal mimarlığa örnek olduğu düşünülmektedir. Hisarözü'nde yapılar, sahibi tarafından yerel yapı malzemesi kullanılarak inşa edilmiştir. Kırsal alan ile ilgili ekonomik faaliyetler ya da yaşam tarzlarına yönelik bilgiler ise, günümüzde de mevcut olan konut, samanlık, ambar, ahır gibi yapılardan okunmaktadır. Kırsal mimari miras ve bulunduğu alan olarak Hisarözü Köyü incelendiğinde Göynük ve çevre illere büyük oranda göç vardır. Bu göçün ana nedenleri, eğitim durumunun sağlanamaması ve geçim kaynağı olan tarım ve hayvancılığın ekonomik anlamda yetersiz kalması gibi durumlardır. Bu durumlardan dolayı özellikle genç nüfus alanı terk etmekte ve kırsal alan atıl hale gelmektedir. Kullanılmayan konutların bakımları yapılmamakta ve zamanla yitirilmektedir. Kırsal alanlarda sürdürülebilirliğin sağlanabilmesi için gerekli çalışmaların yapılması gerekmektedir.

Bu bağlamda çalışma kapsamında özgün donatısını korumuş kırsal mimari mirasa örnek teşkil eden Hisarözü Köyü, güncel koruma sorunsallarına (yeni yapım teknikleri, onarma yerine terk, göç vb.) ev sahipliği yapmasından dolayı incelenmektedir. Geleneksel mimarinin yoğun olduğu yerleşimin envanter çalışmaları yapılmış, yapısal özellikleri ve alandaki sorunlar irdelenmiş, sözlü tarih çalışmaları yapılmış, kırsal mirasın sürdürülebilirliği üzerine önerilerde bulunulmuştur.

\section{Kirsal Miras ve Koruma}

Koruma kavramı ilk olarak tarihte belli bir kimliği olan yapılarla başlamıştır. Yapılar ya orada yaşayan halk tarafından ya da vakıflar aracılığıyla korunmuştur. Bu yapıların korunmasında gözetilen durum ise yapının 
sağlamlığ ve kullanılabilirliğinin devam etmesi olmuştur. Günümüzde ise tek yapı ölçeğinde kalmamış yine bir kimliği olan dokunun da miras olduğu gözetilerek sokak, mahalle, kır, kent gibi alanların da korunmasına gidilmiştir. Çünkü bu alanlar yapıldıkları dönemin mimarisine ve sosyal yaşantısına 1şık tutmaktadır (Ahunbay, 2017).

Tarihi değer taşıyan anıtların ya da kent ve kent içindeki alanların korunmasına yönelik çalışmalar sürdürülürken, Anadolu kültürünün oluşmasında temel unsurlardan biri olan kırsal alanların korunması ise son yıllarda gündeme gelmiştir. Yine Hisarözü Köyü örneğinde de görüldüğü gibi halkın yaşamını devam ettirdiği alanları değerli görmemesi ve devlet kurumlarının bunun üzerinde durmaması birçok yerleşimin yok olmasına neden olmuştur. Daha sonra yitirilen bu değerlerin farkına varılmasıyla yapılan düzenlemelerde devlet eliyle restore çalışmalarına gidilmiş ve bu farkındalığın sonucunda ise geleneksel yaşamın izlerini süren köyler de korumaya değer görülmüştür. Fakat koruma bilincine geç sahip olunması, kentsel ve kırsal alanlarımızın büyük çoğunluğunun kimliğini yitirmesine sebep olmuştur (Eres, 2016). Hisarözü Köyü bu bağlamda geleneksel yaşamın izlerini süren, özgünlügünü büyük oranda koruyan ve kimliğini yitirmeyen bir yapıya sahip olduğu için kırsal mimari miras niteliğinde olup üzerinde çalışılmaya değer görülmüştür.

Kuban, Türkiye' de bulunan kırsal mimarinin korunması düşüncesinde kültür ve ekonomik boyutu tartışmıştır (Kuban, 2001, s.224). “Toplumsal, kültürel ve ekonomik nitelikleri göz önüne alınacak olursa, Türk kentlisinin eski konutları sıhhileştirmesi için yatırım yapamayacağı ve yatırım yapma gücüne sahip birkaç kişinin de kültürel eğilimleri yüzünden böyle bir tutuma sahip olmayacakları bir olgu olarak kabul edilebilir." diye tartıştığ 1 bu olgu Hisarözü'nde de görülmektedir. Köyde yaşayan halk evlerini onarmak yerine yenisini tekrar inşa etmeyi tercih etmektedir. Bu nedenle bazı konutlar, kullanıcı tarafından doku içinde yenisinin yapılması, kırsal yerleşkede yaşayan halkın köyü terk etmesi, hissedarlık durumları gibi nedenlerle kullanılmamaktadır.

Günümüzde sürdürülmeyen bir yaşam düzenine sahip olan Hisarözü Köyü, yöreye özgü yapı malzemesi ile iklim koşullarının olanak verdiği şekilde her ailenin sahip olduğu ahır, samanlık, ambar birimlerinin yan yana geliş biçimi ile dokuyu oluşturmaktadır. Köyde yapılan sözlü görüşmelere göre halk içinde yaşadığ 1 dokuyu korumaya değer görmemekte ve yaşadıkları konutlara eski ve döküntü gözüyle bakmaktadırlar. Rapoport'a göre soruna 'eski' gözüyle bakmak yerine sorun, belleğe yerleşen 
çevresel faktörlerin negatif yönü olarak incelendiğinde çözüm üretilebilir. Bu kapsamda neden dokuya 'eski' olarak bakıldığı tespit edilebilir (Rapoport, 2002).

Böylece Hisarözü'nde yaşayan halkın bilinçlendirilip onların istek ve arzuları doğrultusunda ele alınmalıdır. Kırsal alanda yaşamın yitirilmeye başlaması, özgün mimarinin terk edilmesi gibi Hisarözü Köyü’nde de görülen bu durumlar, alanların kültür mirası olarak görülüp korunması gerekliliğini ortaya koymuştur. Bu koruma gerekliliği objektif boyutta ele alınmalıdır. Hisarözü Köyü, sürdürülebilir yaşam düzenine sahip olduğunda doğal ve üretim malzemesi ile kırsal peyzaj bütünlüğünü devam ettirebilecek özelliktedir.

\section{Geçmişten Günümüze Hisarözü Köyü / Göynük}

Çalışmaya konu olan Hisarözü Köyü, Bolu ilinin Göynük ilçesine bağlı bir köydür. Bolu iline $107 \mathrm{~km}$ uzaklıktadır. Göynük ilçesine ise $7 \mathrm{~km}$ uzakta olup ilçenin kuzeyinde yer almaktadır. Hisarözü, batıda Bulanık Köyü, güneyde ilçe merkezi, doğuda Çubuk ve Örencik Köyleri ve kuzeyde Sakarya/Akyazı ile çevrelenmiştir (Şekil 1).

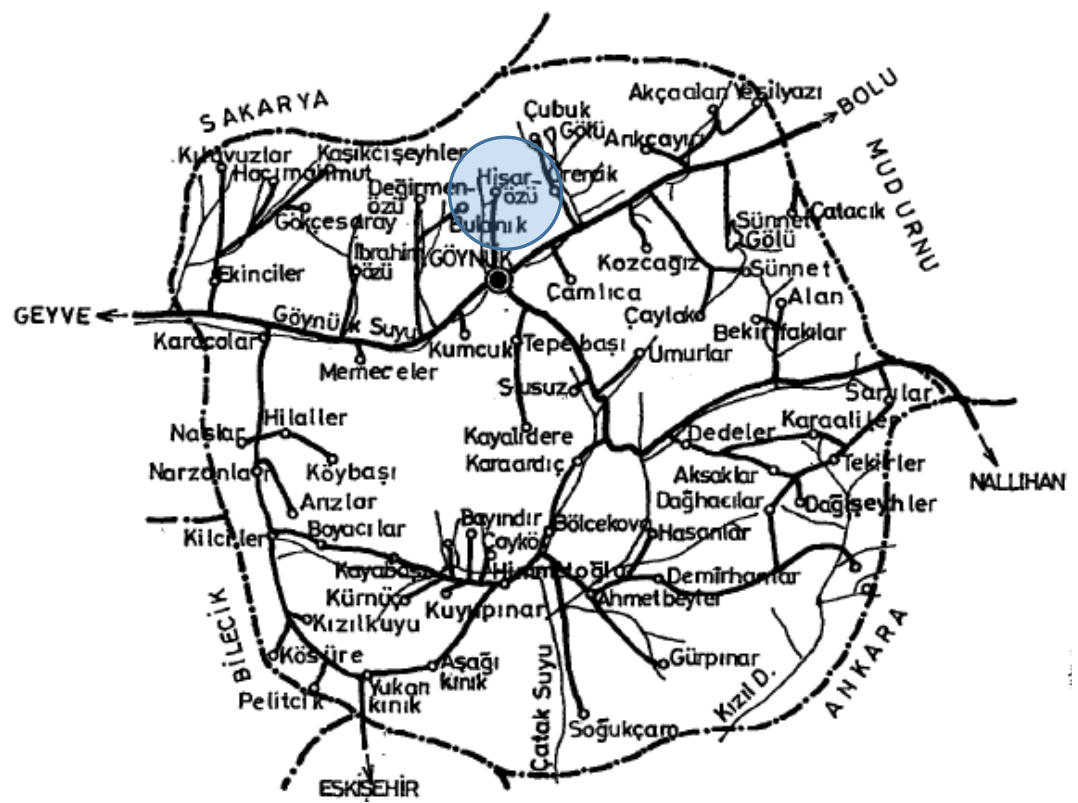

Şekil 1. Göynük İlçesi ve Köyleri (Kaynak: Erdem, 1996, s. 5) 
Göynük ilçe merkezinin Beybahçesi Vadisi'nin ortasından geçen Beybahçesi Caddesi üzerinden Hisarözü Köyü yoluna bağlantı sağlanır. Köyün güney kesimine yerleşen tarım arazilerinin arasından geçerek ulaşılan mahalleler 3 ayrı noktada kurulmuştur. Bu mahalleler vadinin ortasindan geçen Hisarözü köy yolunun doğu ve batı yönlerine topografyaya uygun bir şekilde yerleşmiştir. Hisarözü Köyü'nün tarihsel süreçteki yeri, köyün fiziki durumu ve sosyo - ekonomik gelişimi ve tüm bunların mimari üretime yansıması ele alınmıştır. Söz konusu yerleşim biriminin bağlı bulunduğu Göynük ilçesi ile olan tarihi, coğrafi ve ekonomik ilişkisi ortaya konulmuştur.

\section{Tarihsel Süreç}

Başbakanlık Osmanlı Arşivi'nde, Tapu Tahrir Defteri adlı arşiv belgesinde Hisarözü Köyü'nün adı mülk arazileri bölümünde geçmektedir. Bu araştırma kapsamında Hisarözü'nün tarihinin 16. yüzyıla kadar dayandığı görülmektedir. Ekonomik yapının tarıma dayandığ 1 Osmanlı'da mülk arazileri genellikle şehrin yakınında bulunmaktadır (Toprakeşenler, 1994). Hisarözü Köyü de coğrafi konum olarak Göynük ilçe merkezine yakın konumdadır. Yine köy halkı ile yapılan sözlü görüşmelerde de tarım arazilerinde ve köye ait olan mezarlıkta kemik kalıntılarının çıktı̆̆ söylenmektedir. Bu değerlendirmeler sonucunda Hisarözü'nün tarihsel süreci günümüzde bağlı olduğu Göynük ilçesi ile beraber ele alınmıştır.

Göynük'e ilk yerleşim Frigler tarafından M.Ö. 1200 yıllarda gerçekleşmiştir (Akurgal, 1998) ve o dönemde Bithynia olarak anılan Bolu ve çevresini aldıkları bilinmektedir. Bu nedenle Göynük ilçesinde Bithynia ile Frig uygarlıklarına ait eserler bulunmaktadır. M.Ö. 74 yılında ise Göynük'ün hâkimiyeti Romalılara geçmiştir ve Göynük sınırları içinde olan Himmetoğlu Köyü'nde Roma dönemine ait olan hamam kalıntıları bulunmaktadır (Dikmen, Toruk, 2015). Roma İmparatorluğu'nun ikiye ayrılmasıyla Bizans hâkimiyetine geçen Göynük'te, Bizanslılar Selçuklulara karşı bölgeyi savunmak için kale yapılarını çoğaltmışlardır. 1200'lü yılların sonlarına doğru ise Bizans yönetimi zayıflamıştır ve birçok köyde bu döneme ait yapı kalıntılarına rastlanmaktadır (Anonim, 1998).

1071 Malazgirt Savaşı'ndan sonra Kutalmışoğlu Süleyman Bey'in Bolu bölgesini Bizanslılardan almasıyla hâkimiyet Selçuklulara geçmiştir (Kılıç Benzer, 2006). Daha sonra Göynük; Taraklı, Yenice ve Mudurnu, Orhan Bey'in oğlu Süleyman Paşa tarafından alınarak, 1331 veya 1332 yılında 
Osmanlı topraklarına katılmıştır (Öden, 1999). Osmanlı Devleti yönetimine geçtiği zamanda nüfusunun Rum olduğu bilinen Göynük'te (İbn-i Batuta, H.1330), 17. yüzyıla bakıldığında Rumların yerini tamamen Türklerin aldığ1 görülmektedir (Evliya Çelebi, 1975). Osmanlı döneminde ikmal ve konaklama merkezi olarak kullanılan Göynük, Osmanlı Devleti ile Asya ve Batı ülkelerini ve İstanbul ile Anadolu'yu birbirine bağlayan 'Bağdat Yolu' üzerinde bulunmaktadır. 19. yüzyılda Ermenilerin ve Rumların geldiği Göynük (Yurt Ansiklopedisi, 1982), bu yüzyıldan sonra durağan bir yapıya sahip olmuştur.

10 Ekim 1923'te Göynük, Bolu ilinin ilk ilçelerinden biri olmuştur (Kılıç Benzer, 2006). Erken Cumhuriyet Dönemi'nde konut dokusunda önemli bir değişim geçirmeyen Göynük, 1950'li yıllara kadar kendini korumuştur (Dikmen, Toruk, 2015). Özellikle 1951'de uygulanan imar planı sonucu 'İstanbul-Ankara' yolunun merkezden geçirilmesiyle yanlış kentleşme politikaları uygulanmıştır (Erdem, 1996). Bu durum, güzergâh üzerinde birçok köy yerleşkesinin oluşmasına da sebep olmuştur. Ekonomisinin tarım dışında ticarete de dayalı olduğu Göynük ilçesinin merkezinden geçen 'İstanbul-Ankara' yol aksının Sakarya' ya kaymasıyla birlikte ticari faaliyetler durgunlaşmıştır.

\section{Fiziki Yapı}

Göynük, morfolojik olarak akarsuların derin vadiler aştığı dağlık ve engebeli bir yapıya sahiptir. Arazinin 3/4'ü dağlık ve ormanlık alanı kaplarken, 1/4'ü ise tarım alanı ve akarsuları içermektedir (Erdem, 1996). Göynük ilçesinin kuzeyinde Çubuk, Hisarözü ve Değirmenözü, doğusunda Gölözü, batısında Göynük Suyu, güneyinde Çatak Suyu yer almaktadır (Bolu il Yıllığı, 1973).

Morfolojik olarak dağlık ve engebeli bir yapıya sahip olan köyde kuzey-güney doğrultusunda vadi bulunmaktadır. Yerleşim, Hisarözü sınırları içerisinde güneybatı bölgesinde olup bu vadi yamaçlarındadır. Hisarözü Köyü; Merkez Mahallesi, Şabanlar ve Hapşanlar Mahalleleri olmak üzere 3 mahalleden oluşmaktadır. Bu coğrafi yapı geleneksel mimarinin oluşmasına zemin hazırlamıştır. Yerleşimler vadi yamaçlarına ve dere kenarlarına konumlanmıştır. Merkez Mahallesi doğu kolu, Şabanlar ve Haşanlar Mahalleleri batı kolunu oluşturur (Şekil 2). Düzensiz, organik bir biçimlenmeye sahiptir. Bunun nedeni arazinin dağlık olup vadi yamaçlarına yerleşmesi ve su kaynaklarının bol olmasıdır. 


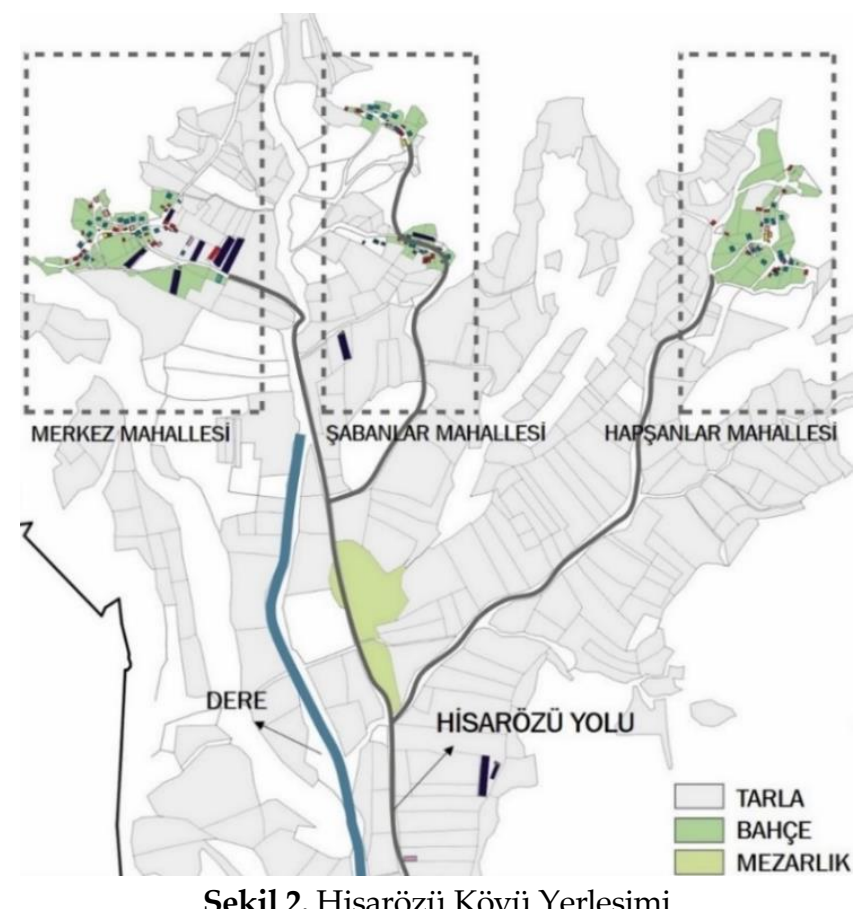

Şekil 2. Hisarözü Köyü Yerleşimi

Göynük ilçesinde Karadeniz ikliminin yanı sıra karasal iklimin etkileri de görülmektedir. Bu nedenle kışlar soğuk ve karlı, yazlar kurak ve sıcak geçer. Kış aylarında yağan kar uzun süre yerden kalkmaz. Yağışın çok olduğu aylar, aralık ve ocak aylarıdır; yağışın çok az olduğu ay ise ağustos ayıdır (Bolu İl Yıllığı, 1967). İklim yapısı konutların plan şemalarını etkilemiştir ve genellikle kapalı sofalı plan şeması kullanılmıştır.

“İlçe merkezi ve ilçe gelişme alanları; silisli tabakalardan oluşmuş, II. ve III. zaman devirlerine ait, çökelme sonucu meydana gelmiş tortul araziler üzerinde bulunmaktadır." (Akcan, 1967, aktaran Erdem, 1996, s. 9). Göynük ilçesi 1. derecede deprem kuşağ1 ile 2. derecede deprem kuşağ1 arasındadır (Bolu İl Yıllığı, 1973). İlçenin kuzey kısmı 1. derece deprem bölgesi, güney kısmı 2. derece deprem bölgesidir. Göynük ilçesinin geçirdiği depremlerden çok az hasarla çıkmasının ana nedeni, yapıların depreme dayanıklı, ahşap karkas strüktürde yapılmış olmalarıdır.

Göynük ilçesinde çayır ve mera alanları, ormanlık alanlar ile iç içedir. Morfolojik yapının eğimli ve ormanlık olması tarımsal faaliyetleri kısıtlamaktadır. Bağ ve bahçeler, dere kenarlarına konumlanmıştır. Yerleşme 
alanındaki topraklar; yamaçların çok dik, toprağın sığ ve taşlı oluşu, hafif tuzluluk, şiddetli erozyon ve drenaj bozukluğu gibi nedenlerden dolayı tarıma elverişli değildir (Erdem, 1996, s. 10). Orman alanlarının geniş yer kaplaması yapıların strüktürel oluşumunda etkili olmuştur ve yapılar ahşap karkas sistem ile oluşturulmuştur.

\section{Sosyo Ekonomik Durum}

Günümüzde tarım ve hayvancllık ekonominin alt yapısını oluşturmaktadır. Göynük ilçesi, iklim çeşitliliği ve toprak yapısından dolayı zengin ürün yapısına sahiptir. Tarım ürünlerinin en başında buğday yer alır. Tarım alanlarında buğdaydan başka arpa, yulaf, şeker pancarı, pirinç, baklagiller gibi ürünler yetiştirilmektedir. Hayvancllı̆̆ın en çok geliştiği alan ise tavukçuluktur. İlçenin neredeyse tüm köy yapısında yumurta ve et piliçleri yetiştirilmektedir. Bununla beraber arıcılık, küçükbaş ve büyükbaş hayvancilık da yapılmaktadır.

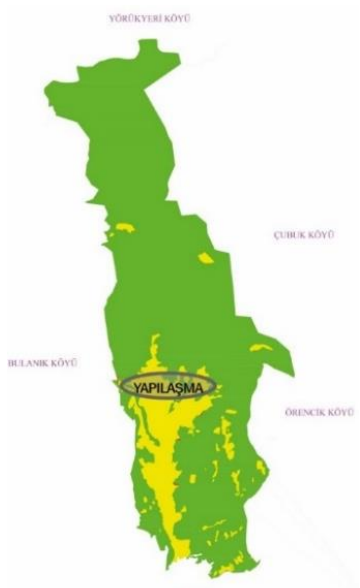

Şekil 3. Hisarözü Köyü Sınırları Tarım Arazisi ve Ormanlık Alan Dağılımı (Kaynak: Göynük Belediyesi Arşivi)

Köyün ekonomisi tarım ve hayvancılığa dayalıdır. Özellikle de yumurta ve besi tavukçuluğudur. Tarım arazileri köyün güneyinde ilçe merkezinin geliş yönünde konumlanmıştır. Ürünlerin en önemlileri buğday, arpa, yulaftır. Sebzecilik genelde kendi ihtiyacını karşılamaya yöneliktir. Kendi kendine yetebilen bir köy iken sosyo-ekonomik açıdan bakıld1- 
ğında köy halkının ilçe merkezi ya da komşu illere göç edip bu kent merkezlerindeki işlerde çalışmaları tarımın köy halkının ihtiyacını karşılamadığını göstermektedir. 1990’lı yıllarda Erpiliç'in kurulmasıyla birlikte köyde yaşamını sürdürmeye devam eden halkın kümes hayvancılığı yapmaya başladığı gözlenmektedir. Şekil 3'e bakıldığında sarı ile gösterilen bölge tarım alanlarına aittir ve bu alanlar vadi içine yerleşmiştir yeşil ile gösterilen bölge ise ormanlık - engebeli arazilerdir (Şekil 3).

Göynük ilçesinin sosyo-ekonomik yapısına bakıldığında sosyal hayat, gelir durumu ve kültürel farklılığın bulunmadığı görülmektedir. Kent merkezinde geleneksel yöntemler ile inşa edilmiş yapılar görülürken günümüzde bu üretim kaybolmuştur. Tarihte Göynük ilçesine bakıldığında büyük aile yapısı görülmekte ve bu durum plan şemalarına da yansımaktadır. Fakat zamanla büyük aile yapısından çekirdek aile yapısına doğru bir geçiş olmuştur. Eğitim durumu ya da iş olanakları nedeniyle genç nüfus çevre illere göç etmeye başlamıştır.

Tablo 1. Nüfusun yıllara göre dağılımı

\begin{tabular}{lrrr}
\hline Y1l & Toplam Nüfus & Erkek & Kadın \\
\hline 2017 & 114 & 56 & 58 \\
\hline 2016 & 111 & 55 & 56 \\
\hline 2015 & 110 & 54 & 56 \\
\hline 2014 & 109 & 56 & 53 \\
\hline 2013 & 107 & 52 & 55 \\
\hline 2012 & 114 & 54 & 60 \\
\hline 2011 & 89 & 44 & 45 \\
\hline 2010 & 91 & 44 & 47 \\
\hline 2009 & 93 & 43 & 50 \\
\hline 2008 & 104 & 49 & 55 \\
\hline 2007 & 91 & 43 & 48 \\
\hline
\end{tabular}

Hisarözü Köyü'nde ekonomik yapının durgunluğu, eğitim, sağlık gibi nedenlerden dolayı nüfus gelişimi kısıtlı olmuştur. Genelde dışa göç veren, doğal nüfus artış hızı ise düşük olan bir yerleşmedir. Genç nüfus, ilçe merkezinde ya da komşu illerde ikamet etmektedir. Yerleşmede genellikle yaşlı nüfus kalmıştır. Türkiye İstatistik Kurumu (TUIKK) 2017 yılı verilerine göre köyün nüfusu 58 kadın ve 56 erkek olmak üzere toplam 114 kişiden oluşmaktadır. Verilere baktığımızda 2007-2008 ve 2011-2012 yıllarında artış olmuş onun dışında durağan hareket etmiştir (Tablo 1). 


\section{Kırsal Mimari}

Göynük kırsal yerleşmeleri köy, mahalle ve yaylalardan oluşmaktadır. İlçe, 67 köy ve bu köylere bağl1 65 mahalle olmak üzere 132 yerleşim biriminden oluşmaktadır. "Göynük İlçesi kırsal yerleşmeleri küçük nüfuslu olup, sürekli göç vermektedir. Göynük ve çevresi dağınık yerleşme düzenine sahiptir. Arazinin dağlık ve su kaynaklarının fazla olması bu yerleşme şekline etki etmiştir." (Kılıç Benzer, 2006, s. 194).

Hisarözü Köyü de Merkez Mahallesi, Şabanlar ve Hapşanlar Mahalleleri olmak üzere 3 mahalleye sahip olup organik doku ve dağınık yerleşmeye sahiptir. Köy dokusunun yerleşiminde büyük etkisi olan Hisarözü Deresi günümüzde neredeyse hiç akmamaktadır. Arazi kullanımına bakıldığında; genellikle çayır ve meraların geliştirilmesine uygundur.

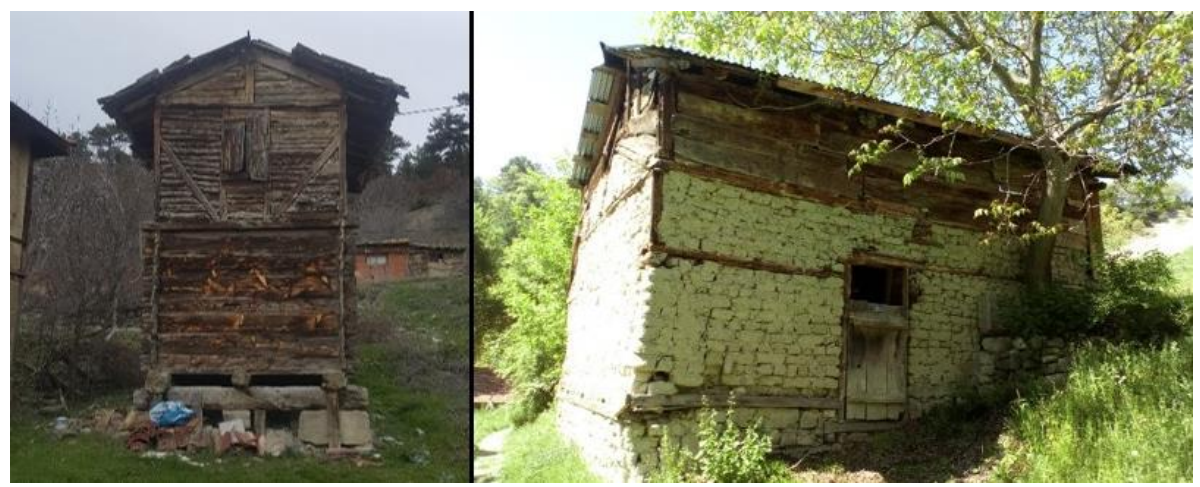

Şekil 4. Ambar ve Samanlık Yapısı

Geleneksel dokuyu içeren Hisarözü'ne bakıldığında 3 temel yapıdan bahsedebiliriz. Bu yapılar konut, ambar ve samanlıktır. Köy evlerinin bazıları bahçe içine konumlanmıştır, bu bahçe sınırları ahşap çit ya da tel ile oluşturulmuştur. Genellikle her evin yanında halkın 'ambar' adını verdiği serenderler mevcuttur (Şekil 4). Serender, köy halkının tahılını, yiyeceğini sakladığı, kuruttuğu, kışlık odununu depoladığı yerdir. Yapının temel unsuru ahşaptır. Samanlık ise ekinlerin harmanda dövülüp taneleri ayrıldıktan sonra kalan sapların hayvanlara yedirilmek için saklandığı yerdir (Şekil 4). Samanlık yapısının temel unsuru ise taş örgüdür. Bazılarında ise taş örgü üstüne ahşap karkas sistem kullanılır. Dokuya bakıldığından evlerin zemin katı ahır olarak kullanılırken samanlık yapıları konutların yakınlarına inşa edilmiştir. 


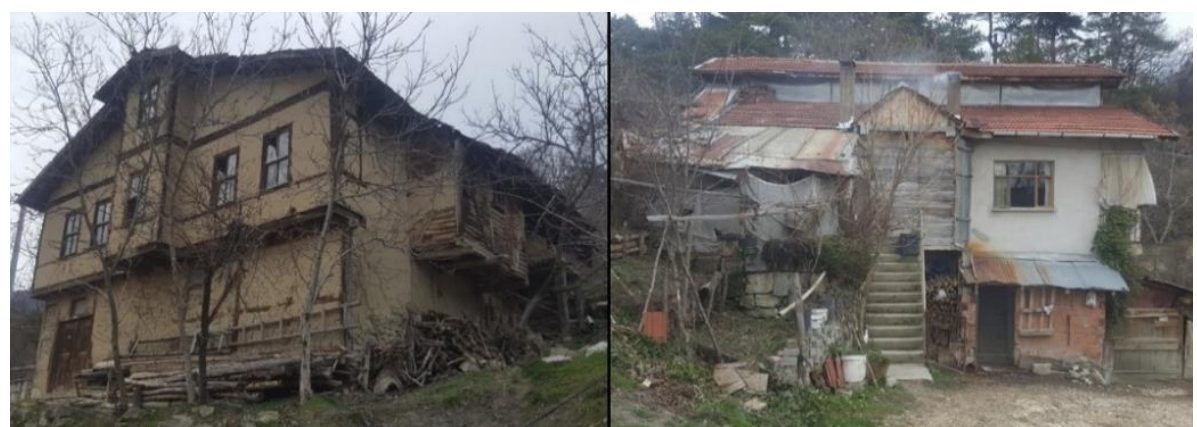

Şekil 5. Geleneksel Konut Yapısı ve Yeni Yapılaşma

Köy yerleşmesinde konutların çoğu geleneksel yapım tekniği ile inşa edilmiştir. Konutlarda kullanılan ana malzeme genellikle ahşaptır (Şekil 5). Ahşabın yapıda kullanılmasının ana nedeni orman köyü olmasıdır. Ahşap ile birlikte taş ve kerpiç de yerel yapı malzemeleri olarak kullanılmıştır. Yapılar genellikle iki katlıdır. Ahır ya da samanlık olarak kullanılan zemin kat taş örgüden oluşur. Taş örgünün üstüne ahşap karkas sistem arası ahşap dolgu devam eder. Örtü malzemesi olarak ise çoğunlukla kiremit kullanılmıştır. Genellikle yapıların zemin katında iki ayrı giriş mevcuttur. Biri ahır ya da samanlık girişi diğeri ise konut giriş kapısıdır. Birinci katta bulunan yaşam katına merdivenle erişim sağlanır.

Arazide yerel yapı malzemesinin kullanılmadığı beton karkas sistemler de mevcuttur (Şekil 5). Merkez Mahallesi'nin girişinde yer alan kümes yapılarının bazıları kerpiç dolgu iken geri kalanlar beton karkas sistem ile inşa edilmiştir. Köy halkından kümes hayvancılığı ile geçimini sağlayanlar, konut yapılarını da beton karkas sistem ile inşa ederek kümes yapılarının yanına kondurmuşlardır. Diğer iki mahallede kümes yapılanması yoktur fakat yine de köy girişlerinde beton karkas sistem ile inşa edilmiş konutlar mevcuttur.

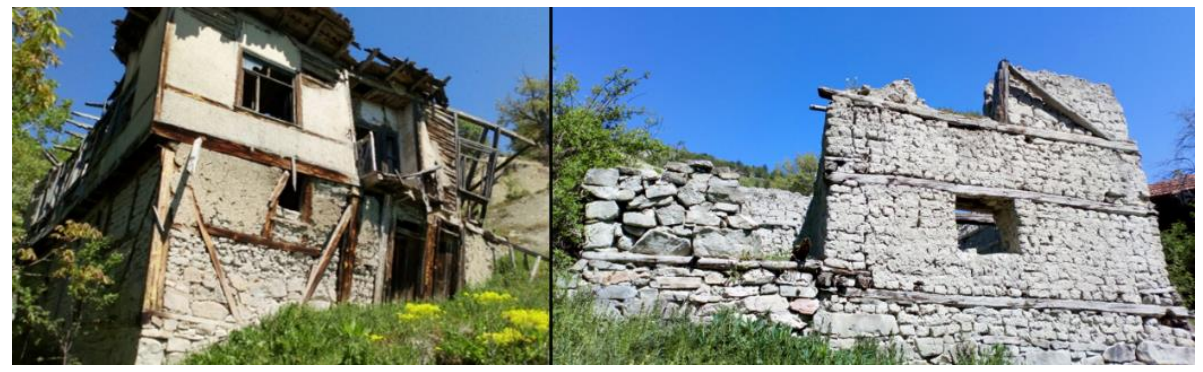

Şekil 6. Harabe Durumdaki Konut ve Samanlık Yapısı 
Alana dair çeşitli tespitler yapıldığında içinde yaşamın devam ettiği konutlarda halkın geleneksel yöntemlerle yapıları onardıkları görülür. Kullanılmayan bazı yapıların bakımsız kaldıkları, bazılarının ise harap durumda oldukları tespit edilmiştir (Şekil 6). Ambarların çoğu günümüzde kullanım dışı kalmıştır. Bunların nedeni toprağa dayalı üretimin zayıflaması ve yaşayanların alanı terk etmesidir. Yapıların bir kısmında betonarme ekler gözlenmektedir. Bazı yapılarda cumba ve çıkmalar bulunmaktadır. Yapılarda özgün ahşap pencere ve kapı detayları, fırın vb. elemanlar görmek mümkündür. Yapılar çeşitli müdahaleler görmüş olsalar bile, özgün cephe karakterini büyük oranda korumaktadır. Bu tespitler çerçevesinde Hisarözü Köyü mahallelerinde bulunan yapıların işlev dağ1lımı, yapım sistemleri ve yapıların taşıyıcı sistemlerinin sağlamlık durumu dişardan gözlem yolu ile incelenmiştir ve sonuçlar Tablo 2 ve Tablo 3 'de sunulmuştur.

Tablo 2. Yapım sistemi ve mahallelere göre işlev dağılımı

\begin{tabular}{|c|c|c|c|c|c|c|c|}
\hline & & \multicolumn{2}{|c|}{$\begin{array}{c}\text { Merkez } \\
\text { Mah. }\end{array}$} & \multicolumn{2}{|c|}{$\begin{array}{r}\text { Şabanlar } \\
\text { Mah. }\end{array}$} & \multicolumn{2}{|c|}{$\begin{array}{r}\text { Hapşanlar } \\
\text { Mah. }\end{array}$} \\
\hline & & Say1 & $\%$ & Sayı & $\%$ & Sayı & $\%$ \\
\hline \multirow{8}{*}{$\begin{array}{l}\text { Geleneksel } \\
\text { Yapım Sis- } \\
\text { temi }\end{array}$} & Konut & 15 & 25,5 & 11 & 34,5 & 13 & 36 \\
\hline & Samanlık & 23 & 39 & 7 & 22 & 12 & 33,5 \\
\hline & Ambar & 8 & 13,5 & 7 & 22 & 5 & 14 \\
\hline & Ahir & 2 & 3,5 & 2 & 6,5 & 2 & 5,5 \\
\hline & Kümes & 3 & 5 & 1 & 3 & & \\
\hline & Cami & 1 & 1,5 & 1 & 3 & 1 & 2,5 \\
\hline & Okul & & & 1 & 3 & & \\
\hline & & 52 & 88 & 30 & 94 & 33 & 91,5 \\
\hline \multirow{3}{*}{$\begin{array}{c}\text { Günümüz } \\
\text { Yapım Sis- } \\
\text { temi }\end{array}$} & Konut & 3 & 5 & 1 & 3 & 3 & 8,5 \\
\hline & Kümes & 4 & 7 & 1 & 3 & & \\
\hline & & 7 & 12 & 2 & 6 & 3 & 8,5 \\
\hline Toplam & & 59 & 100 & 32 & 100 & 36 & 100 \\
\hline
\end{tabular}

Hisarözü Köyü'nde yapıların işlevleri dikkate alındığında konut ve samanlık yapıları sayıca fazladır. Kümes yapılanması ise sadece Hapşanlar Mahallesi içerisinde yoktur. Merkez Mahallesi'nde yerleşim oranı, tüm yerleşme içerisinde $\% 50$ 'dir. Her mahallede yeni yapılaşma görülmektedir. Bu yapılar sayıca çok az olup genellikle mahallelerin giriş kısımlarına konumlanmıştır. Her mahallenin bir camisi vardır. Okul yapısı ise Merkez Mahallesi ile Hapşanlar Mahallesi'nin arasına konumlanan Şabanlar Mahallesi'nde yer almaktadır. 
Tablo 3. Mahallelere göre yapıların sağlamlık durumu

\begin{tabular}{lrrrrrrrr}
\hline & \multicolumn{2}{c}{$\begin{array}{c}\text { Merkez } \\
\text { Mah. }\end{array}$} & \multicolumn{2}{c}{$\begin{array}{c}\text { Şabanlar } \\
\text { Mah. }\end{array}$} & \multicolumn{2}{c}{$\begin{array}{c}\text { Hapşanlar } \\
\text { Mah. }\end{array}$} & \multicolumn{2}{c}{ TOPLAM } \\
\hline & Sayı & $\mathbf{\%}$ & Sayı & $\mathbf{\%}$ & Say1 & $\mathbf{\%}$ & Say1 & \% \\
\hline İyi & 43 & 67 & 25 & 67,5 & 25 & 69,5 & 93 & 68,0 \\
\hline Orta & 13 & 20,5 & 7 & 19 & 11 & 30,5 & 31 & 22,5 \\
\hline Kötü & 8 & 12,5 & 5 & 13,5 & & & 13 & 9,5 \\
\hline Toplam & $\mathbf{6 4}$ & $\mathbf{1 0 0}$ & $\mathbf{3 7}$ & $\mathbf{1 0 0}$ & $\mathbf{3 6}$ & $\mathbf{1 0 0}$ & $\mathbf{1 3 7}$ & $\mathbf{1 0 0}$ \\
\hline
\end{tabular}

Taşıyıcı sisteminde hasarların olmadığı yapılar "iyi" olarak değerlendirilmiştir. "İyi" kategorisine giren yapıların oranı, tüm yapılar içerisinde \%68'dir. Kısmen bozulma ve hasarların görüldüğü, bazı elemanların değiştirilerek sağlamlaştırmaların yapıldığı yapılar "orta" olarak değerlendirilmiştir. Bu kategoriye giren yapıların oranı, tüm yapılar içerisinde $\% 22,5$ 'dir. Y1kılmış ve/veya harabe durumda olan yapılar ise "kötü" kategorisine girmiştir. "Kötü" kategorisinde olan yapıların oranı, tüm yapılar içerisinde \%9, $5^{\prime}$ dir (Şekil 6).

\section{Merkez Mahallesi}

Merkez Mahallesi, Hisarözü Köyü yolunun doğu koluna yerleşmiştir ve organik bir dokuya sahiptir. Yerleşme en çok bu mahallede yer almaktadır. Sayıca en fazla samanlık yapısı görülmektedir. Samanlık yapısı oranı, mahalledeki tüm yapılar içerisinde \%39'dur. Geleneksel doku \%88 iken yeni yapılaşma $\% 12$ oranındadır. Bu sonuçlara göre geleneksel doku kendini büyük oranda korumuştur. Yeni yapılaşma ise konut ve kümes yapılarında görülmektedir. Bu yapılar mahallenin alt eteklerine (güneydoğu bölgesine) konumlanmıştır.

İyi durumdaki yapıların oranı \%67' dir. Bu durumda geleneksel dokunun yarısından çoğunun strüktürel durumunun iyi olduğu görülmektedir. Orta durumdaki yapıların oranı $\% 20,5^{\prime}$ dir ve bu yapılarda genellikle malzeme kaybı olduğu saptanmıştır (Şekil 7). Strüktürel durumun kendini koruyamadığı yapıların oranı ise $\% 12,5^{\prime}$ dir ve bu dilimin çoğunu samanlık yapıları kapsamaktadır. 


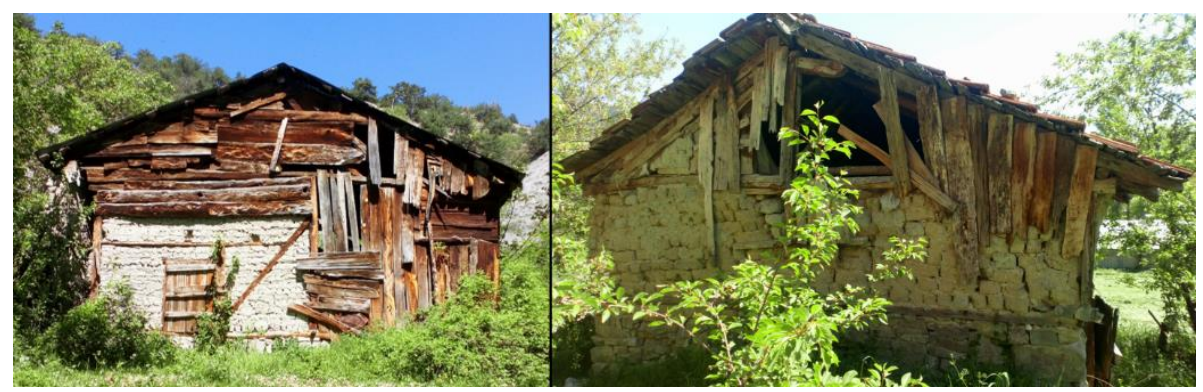

Şekil 7. Orta Durumdaki Samanlık Yapıları

\section{Şabanlar Mahallesi}

Şabanlar Mahallesi, Hisarözü Köyü yolunun batı koluna ve iki bölgeye yerleşmiştir. $\mathrm{Bu}$ mahalle diğer iki mahallenin arasına konumlanmıştır. Yerleşme en az bu bölgede görülmüştür. Yapılar içerisinde \%39 oranında olan konut yapıları çoğunluğu oluşturmaktadır. Mahallenin girişinde günümüz yapım tekniğiyle yapılan ve $\% 3$ oranını kapsayan birer tane konut ve kümes yapısı mevcuttur. Bu kümes yapısı, geleneksel yapım tekniği ile yapılan kümes yapısına ek olarak yapılmıştır. Okul yapısı bu mahallede yer almaktadır ve doku içerisinde oranı \%3'tür. Şabanlar Mahallesi'ne genel olarak bakıldığında mahallenin geleneksel dokusunu bozmadığı gözlenmektedir.

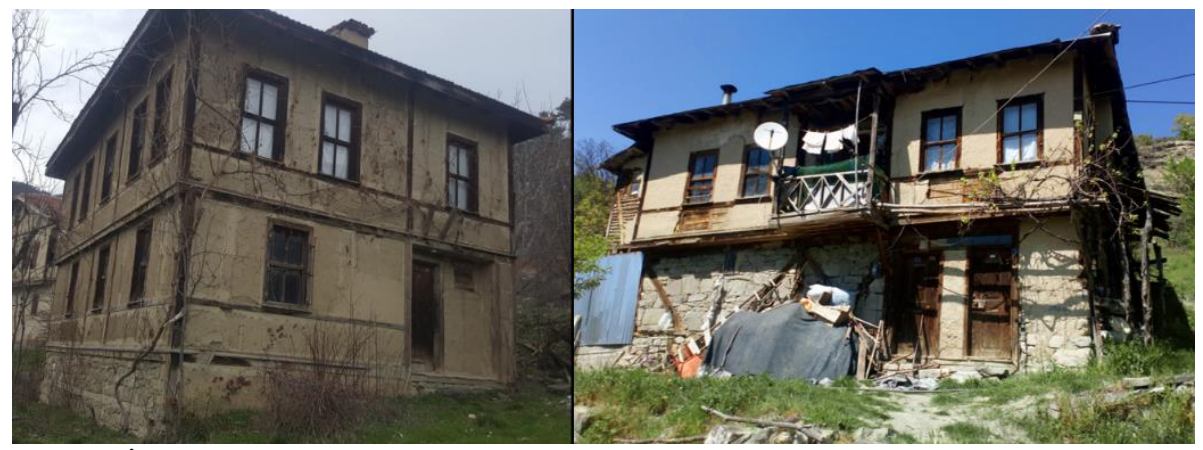

Şekil 8. İyi Durumdaki Konut Yapıları

Mahalle dokusunun sağlamlık durumuna bakıldığında yapıların \%67'5'inin iyi durumda olduğu saptanmıştır (Şekil 8). "Orta" olarak belirlenen yapıların oranı \%19'dur. Bu oranın çoğunluğunu samanlık yapıları oluşturmaktadır ve bu yapıların orta derecede bulunmasının sebebi çatı örtüsünün alt kısmında bulunan ahşapların dökülmesidir. Kötü durumda olan yapılar ise $\% 13,5$ oranındadır. 


\section{Hapşanlar Mahallesi}

Hapşanlar Mahallesi, Hisarözü Köyü yolunun batı koluna yerleşmiştir. Mahalleye ulaşım, Merkez ve Şabanlar Mahallesi'ne ulaşmadan önce Hisarözü Köyü mezarlığının sağ kanadından sağlanır. Mahallenin işlev dağılımına bakıldığında konut ve samanlık yapılarında çoğunluk görülmektedir. Kümes yapılanması sadece bu mahallede yoktur. Mahallenin girişinde $\% 8,5$ oranını kapsayan yeni konut yapıları yer almaktadır. Geleneksel dokuyu oluşturan oran ise \%91,5'dir (Şekil 9). Bu oranlar sonucunda bu mahallenin de dokusunu büyük oranda koruduğu görülmektedir.

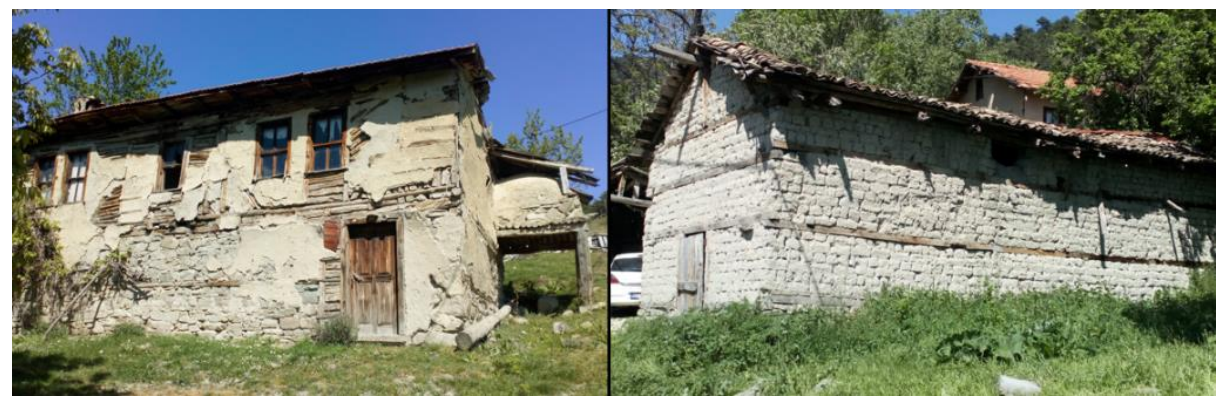

Şekil 9. Geleneksel Dokuyu Oluşturan Yapılar

Sistemin kendini koruduğu yapıların oranı $\% 69,5$ 'dir. Bu oranın yüksek olmasının sebebi yapıların ahşap karkas sistem ile inşa edilmesidir. Orta durumda olan yapıların oranı ise \%30,5'dir. Bu sinifa giren yapilar genellikle samanlık ve ambar yapılarıdır. Bu mahallede strüktürel açıdan kötü durumda yapı bulunmamaktadır.

Belirtildiği gibi Hisarözü Köyü de, geleneksel özelliklerini büyük oranda korumakta olan kırsal mimari bulunduğu için çalışılmaya değer görülmüştür. İklimsel, sosyal ve ekonomik durumları yansıtan köy dokusu ve bu dokuyu oluşturan mimari üretimler Hisarözü'nde bulunmaktadır. Kırsal yaşam biçimi ve mimarisiyle bir bütün halinde olan köy dokusu geçmişten günümüze geçirdiği değişimler mimari ve sosyolojik aç1dan ele alınmıştır. Mimari mirası oluşturan yapıların koruma sorunları ve önerileri sunulacaktır. 


\section{Hisarözü Köyü Koruma Ve Sürdürülebilirlik Sorunları}

\section{Merkez Mahallesi}

Konut yapılarının zemin katı genellikle hayvan barınağı, birinci kat ise yaşam katı olarak kullanılır. Bu nedenle mahallede ahır yapısı çok az sayıdadır. Günümüzde ise sağlamlığını koruyan geleneksel konutların çok azı kullanılmaktadır. Mahallede yaşamını sürdüren yerli halk ile yapılan sözlü görüşmelere göre bu evlerin kullanılmama sebepleri; hissedarlık durumları, yakıt sorunu, bazı konut sahiplerinin köyü terk etmesi, ya da yumurta ve besi tavukçuluğuyla uğraşan halkın kümes yapılarının yanına yeni yapılar yaparak eski yapılara kilit vurmasıdır (Şekil 10).

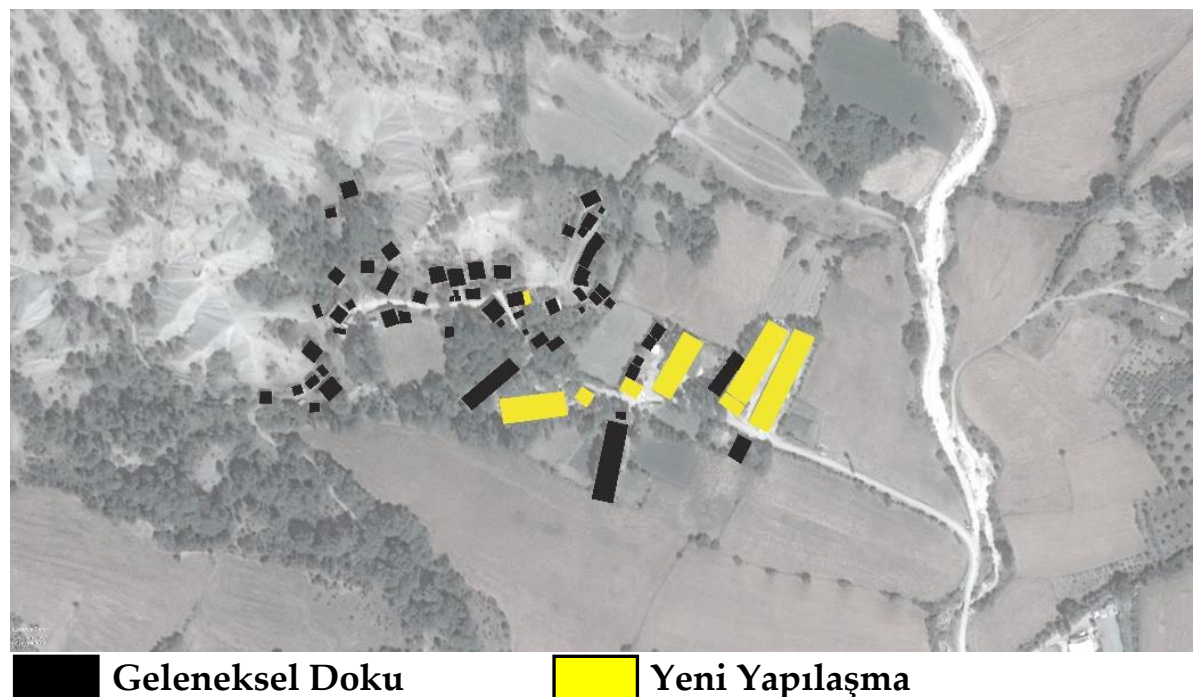

Şekil 10. Merkez Mahallesi

Ambar yapılarının tümü kullanım dışı kalmıştır. Samanlık yapılarının ise bazıları kullanılmaktadır, kullanılmayanların çoğu ise çatılardan ağır hasarlar almıştır. Mahallede 1970'li yıllarda geleneksel yapım tekniği ile yapılan kerpiç dolgu kümes yapıları da bulunmaktadır. Yapılan görüşmelere göre beton karkas sistem ile yapılan kümes yapılarının daha önce kerpiç dolgu olduğu fakat zamanla oluşan hasarlar nedeniyle yıkılıp yerine yenisinin yapıldığı söylenmektedir.

Mahalle camisi 1980'li yıllarda yıkılarak tekrar ahşap karkas sistem ile inşa edilmiştir. Caminin hemen yanında köy odası bulunmaktadır. Bu köy odası önceden toplanma yeri olarak kullanılmakta iken günümüzde imam 
lojmanı olarak kullanılmaktadır. Cami ve lojman 2017 yılında köy halkı tarafından onarılmış ve dış cephesi sıva ile örtülmüştür.

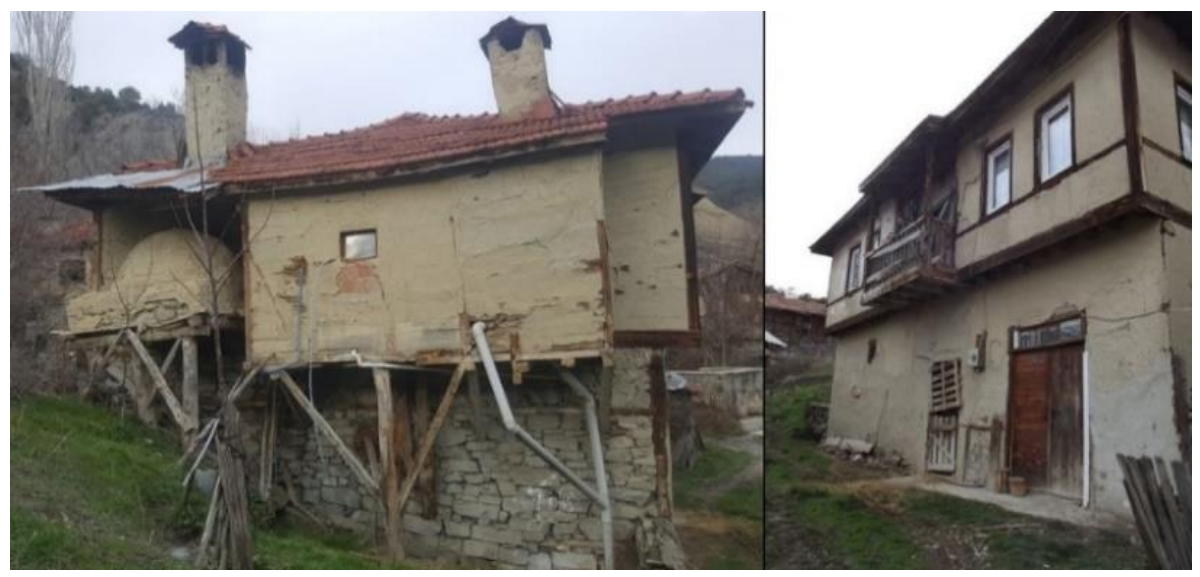

Şekil 11. Mehmet Durmuş Evi

Bu çalışma kapsamında Merkez Mahallesi'nden bir geleneksel konut alanda gözlemlenen plan tipolojisi, mimari özellikleri ve yapım tekniğini anlatması açısından örnek olarak sunulmuştur. İncelenen ve ölçülerek çizimi yapılan geleneksel konut, en az 70 yıllık tarihe sahip olan, köyün eski muhtarlarından Mehmet Durmuş'un evidir (Şekil 11). Konut, mahalle camisinin çaprazında bulunmaktadır. Eğimli bir araziye oturan yapı yığma taş üstüne ahşap karkas sistem arası ahşap dolgu ile inşa edilmiş ve sıvanmıştır. Zemin ve bir kattan oluşan konut yapısının girişi güneydoğu yönündeki cephesinde zemin kattadır. Güneydoğu ve güneybatı cephesinin birinci katında çıkmalar mevcuttur. Zemin kat hayvan barınağı, birinci kat ise yaşam katı olarak kullanılmaktadır. Yaşam katında sofa ve sofaya açılan odalar bulunmaktadır. Yapının güneybatı cephesine fırın eklenmiştir. Kırma çatılı yapı sade bir cepheye sahiptir. Özgün karakterini sürdüren yapıda geleneksel yapım tekniği ile onarımlar yapılmıştır. (Şekil 12). 


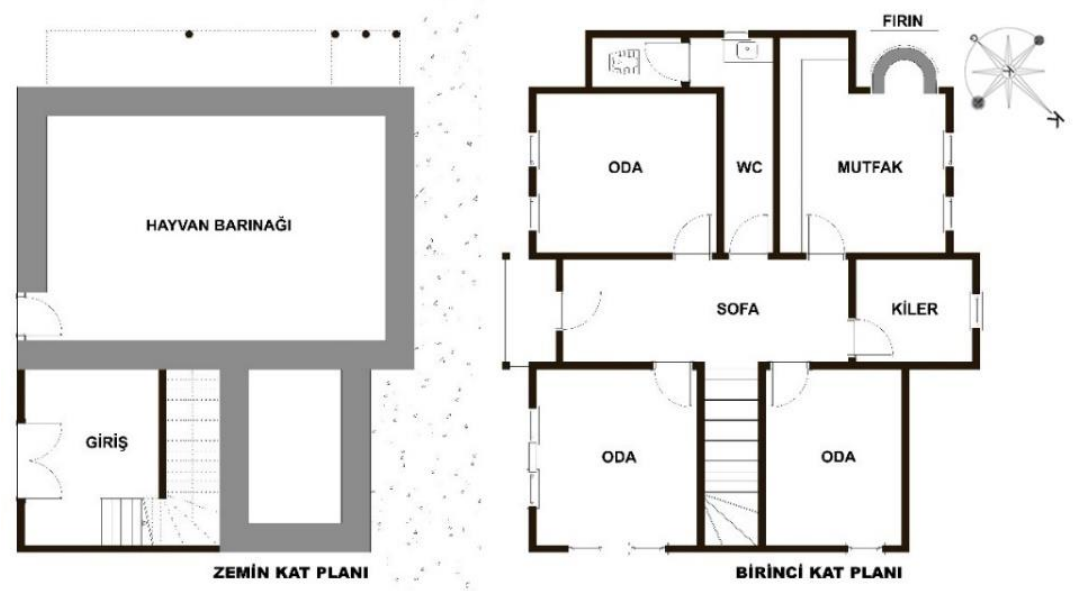

Şekil 12. Mehmet Durmuş Evi ve Plan Şeması

\section{Şabanlar Mahallesi}

Organik dokuya sahip olan mahalle dağ eteğinde yol boyunca sıralanarak konumlanmıştır (Şekil 13). Mahallenin girişinde beton karkas sistemden yapılan bir konut mevcuttur. Geri kalan konut yapılarının hepsi geleneksel yapım tekniği ile inşa edilmiş ve strüktürel açıdan sağlamlığını korumuştur. Konut yapılarının zemin katı hayvan barınağı olarak kullanıldığı için ahır yapısı 2 tanedir.

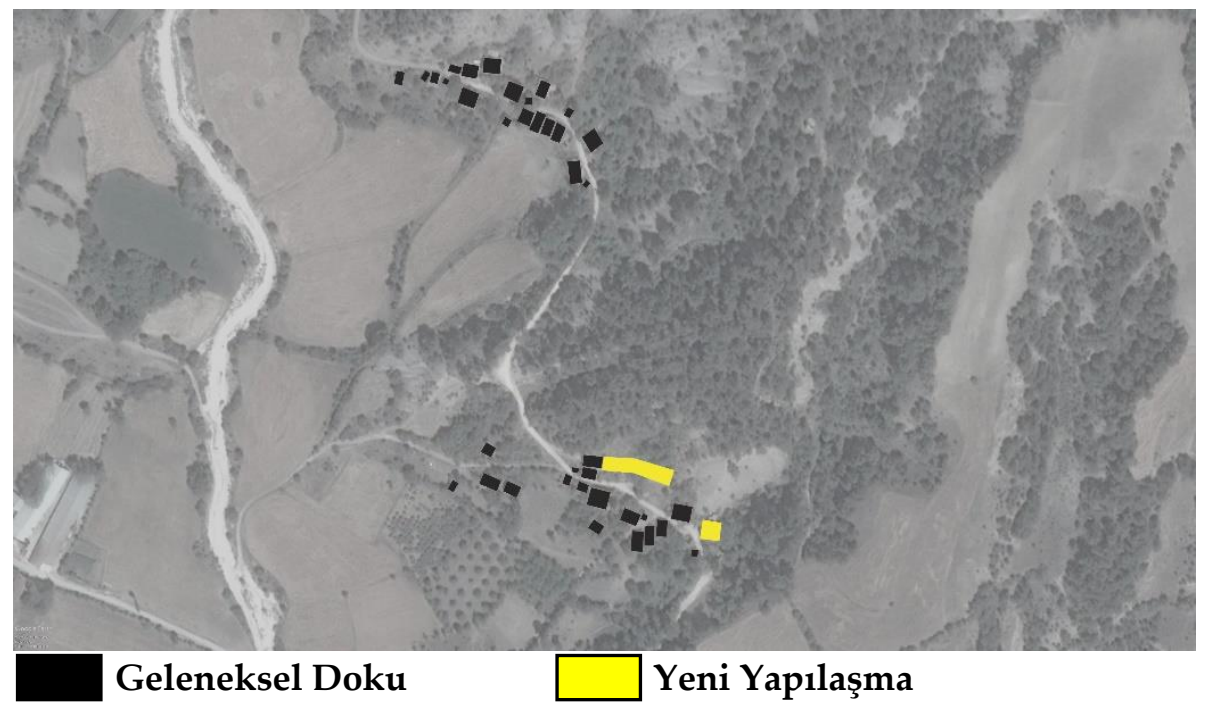

Şekil 13. Şabanlar Mahallesi 
Harabe durumda olanların hepsi samanlık yapısıdır. Sağlamlığını koruyan samanlık yapılarının ise genellikle çatılarında hasarlar vardır. Mahalle içinde bir tane kümes yapısı mevcuttur fakat kullanılmamaktadır. $\mathrm{Bu}$ kümes yapısı hane sahibi tarafından evin arka bahçesine inşa edilmiş ve sonra günümüz yapım sistemiyle ek yapılarak uzatılmıştır (Şekil 14).

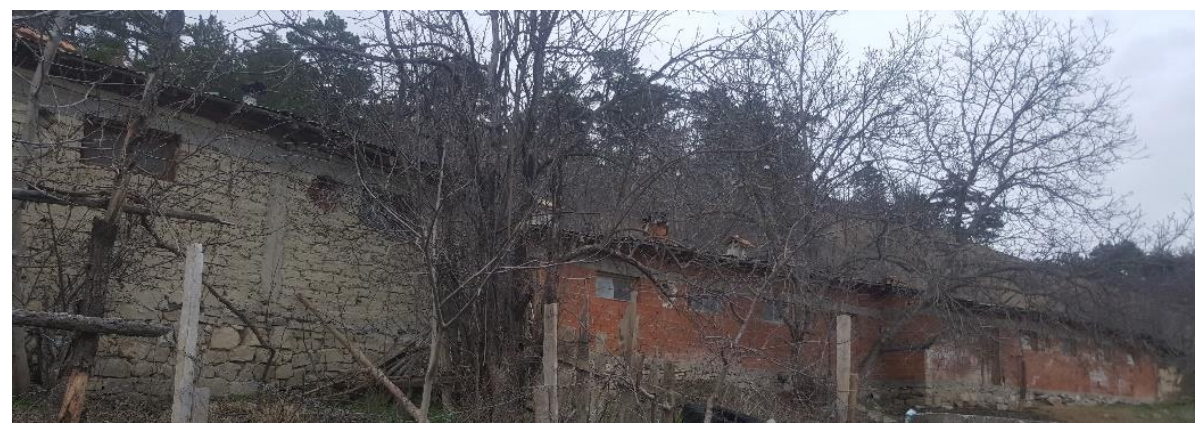

Şekil 14. Kümes Yapısı

Mahallenin alt yerleşkesinde (güneybatı bölgesinde) okul yapısı vardır ve bu yapı 2000'li yılların başında kapatıldığı için kullanılmamaktadır (Şekil 15). Okul bahçesi içinde lojman yapısı ve tuvalet de bulunmaktadır. Cami yapısı ise mahallenin üst yerleşkesinde yer alıp 2003 yılından büyük bir onarımdan geçmiştir. Mahallede konut yapısı az olmasına rağmen iki bölgede de ikişer tane çeşme bulunmaktadır.

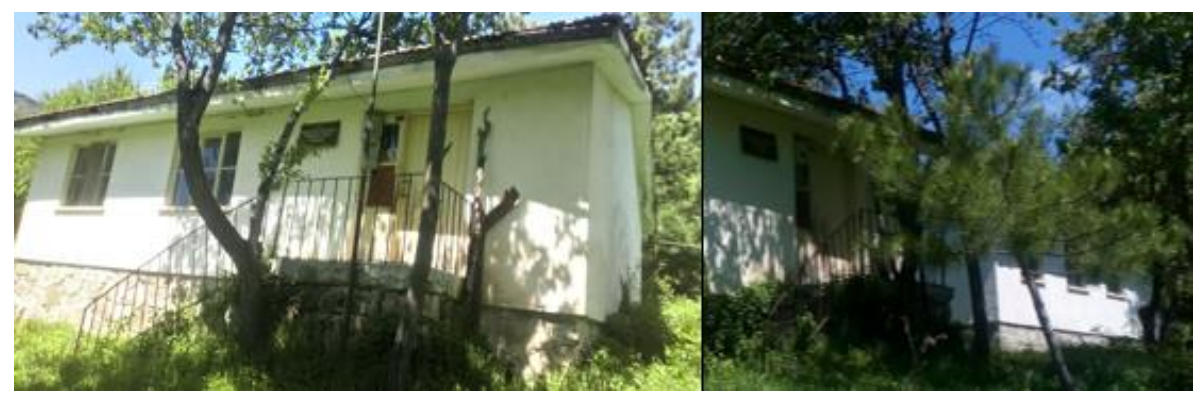

Şekil 15. Okul Yapısı

\section{Hapşanlar Mahallesi}

Yapılar, mahalle camisi etrafına düzensiz bir şekilde konumlanmıştır ve organik bir dokuya sahiptir (Şekil 16). Köy nüfusunun çoğunluğunu 
bu mahalle oluşturmaktadır. Mahalle içinde harabe durumda yapı bulunmamakta ve diğer mahallelere oranla geleneksel yapım tekniği ile inşa edilmiş konut dokularında yaşamın devam ettiği daha çok gözlenmiştir.

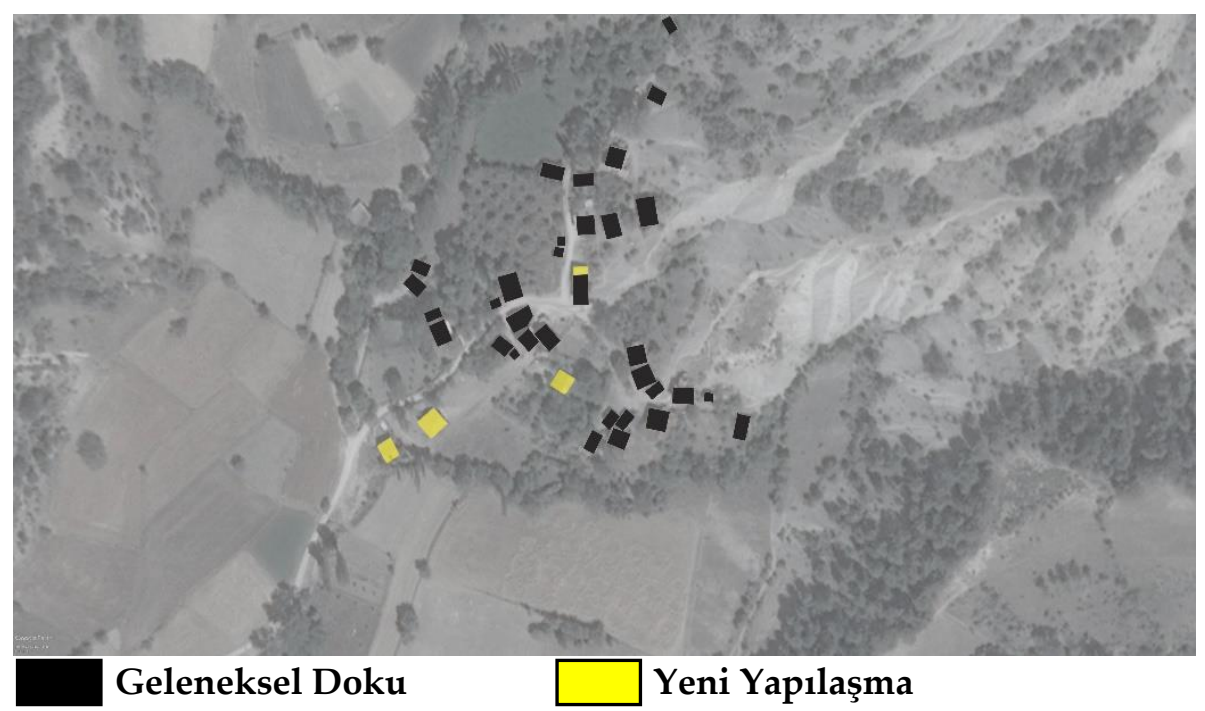

Şekil 16. Hapşanlar Mahallesi

Mahallenin giriş kısmında betonarme karkas sistemden oluşan 2 tane konut yapısı mevcuttur. Girişte ilk bulunan konut yapısının sahibiyle yapılan görüşmede, mahalle yerleşkesinin içinde 1956 senesinde geleneksel yapım sistemi ile inşa edilmiş bir başka konutunun da olduğu öğrenilmiştir fakat hissedarlık durumları nedeniyle kullanılmamaktadır.

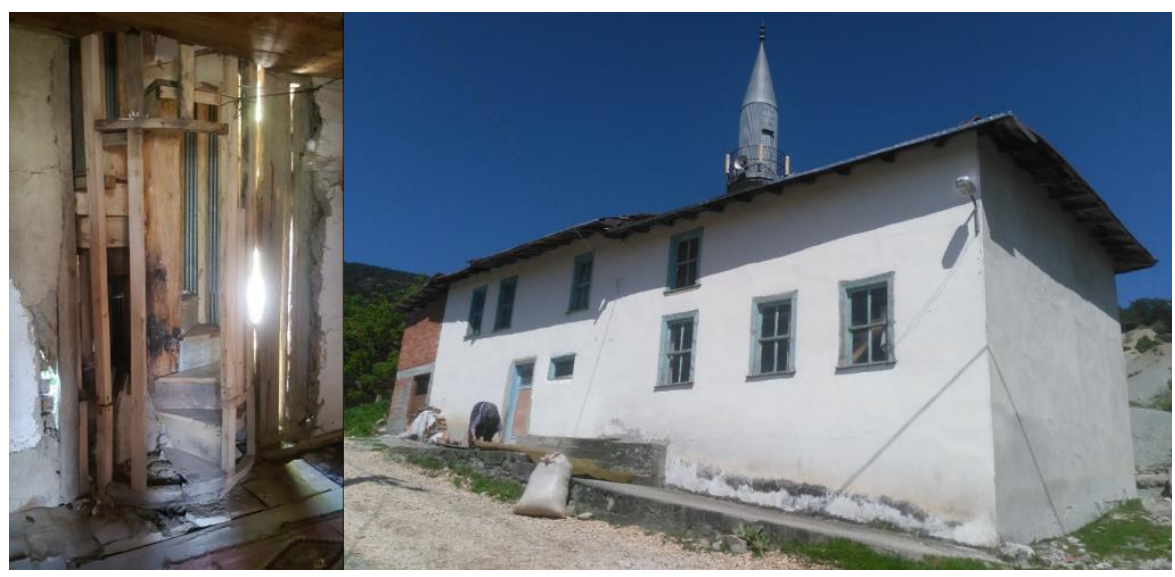

Şekil 17. Hapşanlar Mahallesi Camisi 
Samanlık yapıları ise daha aktif durumdadır. Mahallede yumurta ve besi tavukçuluğuyla uğraşan nüfus olmadığı için yerleşkede kümes yapısı bulunmamaktadır. Mahalle camisi yerleşimin orta noktasında konumlanmış olup geleneksel yöntemlerle inşa edilmiştir (Şekil 17) ve caminin yanında da bir tane çeşme mevcuttur.

Özgünlüğünü henüz yitirmemiş olan Hisarözü'nün kendini korumaya devam edebilmesi için öncelikle yaşamın devam etmesi gerekmektedir. Birçok kırsal mimaride karşılaşılan en büyük sorunlardan bir tanesi geleneksel yöntem ile inşa edebilecek olan ustanın bulunmamasıdır. Fakat Hisarözü'nde yapılan araştırmalara göre köyde hala yaşamını devam ettiren ve geçimini kümes hayvancılığı ile sağlayan Mustafa Demir'in geleneksel inşaat işini bilen bir usta olduğu öğrenilmiştir. Mustafa Demir ile yapılan görüşmede, kendisine ait olan geleneksel konut ve kümes yapısını söküp, bu malzemelerle Göynük ilçe merkezine tekrar evini inşa ettiği, Hisarözü Köyü'ne ise beton karkas sistem ile yeni konut ve kümes yapısı yaptığı öğrenilmiştir. Geleneksel yapım tekniği ile inşayı bilen bir ustanın kendi evini bile beton karkas sistem ile inşa etmesi kırsal mimari miras bilincinin köy halkında olmamasının ve köy dokusuna eski ve döküntü gözüyle bakıldığının ispatıdır.

Köy yerleşkesinde bulunan ve içinde yaşamın devam ettiği bazı konutlara, yaşama yönelik ihtiyaçlarını çözmek için müdahalelerde bulunulmuştur. Yapılara ıslak hacim ya da mutfak mekânı katmak için ekler yapılmıştır. Bu ekler beton karkas sistem arası tuğla örgü ile inşa edilmiştir (Şekil 18). Niteliksiz olarak görülen ekler yapıda yaşamın devam etmesini sağlarken aynı zamanda da geleneksel dokuyu bozmaktadır. Diğer bir müdahale ise yap1larda kapı ve pencere doğramalarının değişmesidir (Şekil 18).Yine bu durum konut içinde yaşamın devam ettiğini gösterirken dokuyu bozan onarımlardir.

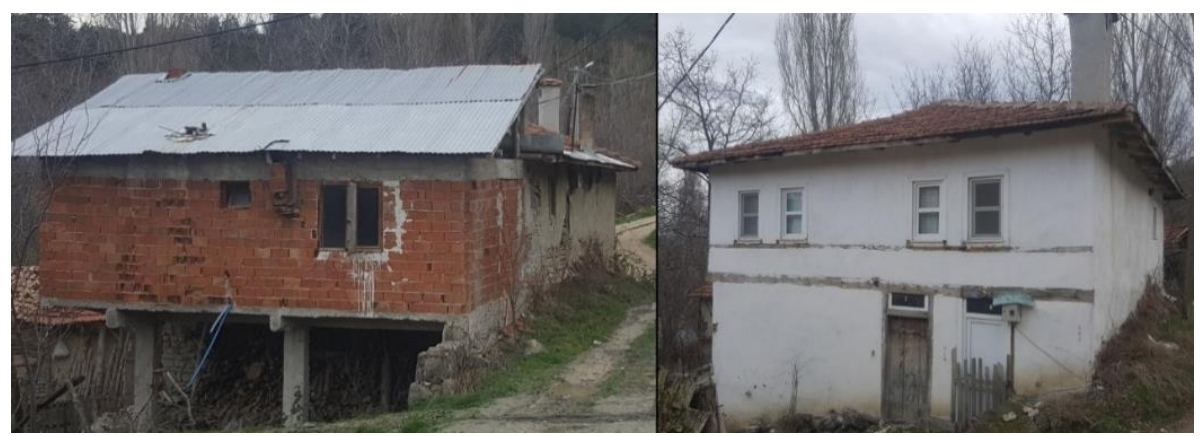

Şekil 18. Ek Yapı ve Özgün Olmayan Doğramalar 
Temel geçim kaynağ 1 tarım ve hayvancılık olan ve bu durumu mimari yapısına yansıtan köy yerleşkesinde ekonomik kazanç durumunun değişmesi nedeniyle önceden kullanılan samanlık ve ambar yapıları günümüzde kullanılmamaktadır. Özellikle ambar yapıları köyün genelinde kullanıma tamamen terk edilmiştir. Köy dokusunda kullanıma terkedilmiş olan yapıların çoğunluğu strüktürel bağlamda sağlamlığını korumuş durumdadır. Yapılan sözlü görüşmelere göre köyün ağır depremler geçirdiği fakat yapıların sadece baca kısımlarında sorunlar çıktığı belirtilmiştir. Bu durum yöreye özgü olan ahşap yapım malzemesinin depreme dayanıklı olduğunun göstergesidir. Hem ekonomik faaliyetlerin değişmesi hem de köyün çoğunluğunu yaşlı nüfusun oluşturması üretimin de yapılamamasına neden olmaktadır. Bu durumlara çözüm üretilmediği takdirde ilerleyen zamanlarda köyde yaşam tamamen yok olacak ve köy dokusu harabe duruma gelecektir.

\section{Değerlendirme ve Sonuç}

Bolu İli, Göynük İlçesi'ne bağlı Hisarözü Köyü'nde yapılan bu çalışmada, kırsal mimari mirasın izleri incelenmiş ve dokunun oluşmasındaki fiziki yapı ve tarihsel süreç ele alınmıştır. Böylelikle özgün dokuya sahip köyün mevcut durumu analiz edilmiş ve tespitler yapılmıştır. Genel olarak bakıldığında kırsal mimari dokunun bütünlügüüü bozmadığını fakat yapıların zamanla strüktürel problemlerinin arttığı gözlemlenmiştir.

Geleneksel yapım tekniği ile yapılan ve sağlamlığını büyük ölçüde koruyan geleneksel konutların çok azında yaşam devam etmekte olup, geneli terk edilmiştir. Kullanılmayan samanlık yapılarının çoğu çatıdan hasarlar almış ve çatılarında çökmeler görülmüştür. Ambar yapılarının ise tümü kullanıma terk edilmiştir. Kırsal alanda bulunan ve zamanla terk edilen bu doku kaybolma tehlikesiyle karşı karşıyadır. Yerel halk zamanla göç etmekte ve yaşamın devam etmediği bu yapıların bakımı yapılmadığı için doğal etkenlere maruz kalarak zamanla yıpranmaktadır. Günümüz yapım tekniği olarak kullanılan beton karkas sistem arası tuğla dolgu ile yeni yapılar inşa edilmekte ve bu teknikle geleneksel konutlara ekler yapilarak kırsal dokunun bozulmasına neden olmaktadır.

Ana geçim kaynağı tarım ve hayvancilık olan yerli halkın ekonomik açıdan gelirini karşılayamaması göçü hızlandırmıştır. Erpiliç tesislerinin 
Göynük'te kurulması nedeniyle günümüzde yumurta ve besi tavukçuluğu ön plandadır. Bu kırsal mimari mirasın korunup sürdürülebilmesi için öncelikle köy dokusunu oluşturan yaşantının göz önünde tutularak çağdaş tasarımlara gidilmesi önerilmektedir. Çünkü yerleşimde yaşant1nın zamanla yok olması, bu yaşantının izlerini süren yapıların da zamanla tahrip olmasına neden olmaktadır. Sadece yapıların korunması ile de oranın kültürel kırsal mirası korunmuş olmaz. Bu durumda orada yaşayan halkın yaşam koşullarının daha iyi olabilmesi için çözümlemeler yapılmalı, çevre dengesi korunmalıdır.

Yapılan sözlü görüşmeler sonucu yapıların, hissedarlık, yakıt sorunu, bazı konut sahiplerinin sosyo-ekonomik nedenlerden köyü terk etmesi gibi durumlardan dolayı kullanılmadığı anlaşılmaktadır. Yerli halk dokunun kırsal mimari miras olduğunun farkında olmayıp geleneksel yapıları eski olarak nitelendirip yeni yapı yapma eğilimindedir. Bu konu üzerinde halk bilinçlendirilerek kırsal doku "yaşayan" miras haline gelebilir.

Dokuda bulunan tüm yapıların tek tek ele alınarak onarımlarının yapılması gerekmektedir. En iyi durumda olan yapılar da bile sıva dökülmeleri görülmektedir. Bu dökülmeler, iç malzemenin havayla direk temas ederek yapının yıpranmasını hızlandıracaktır. Kullanılmayan yapıların çoğunda camların kırıldığı gözlemlenmiştir. Bu durum da yapıya etki edecektir. Yığma taş duvarlarda bozulmalar yerel malzemelerle tamamlanabilir. Ahşap malzemelerde ise eski ve yeni ahşap, ahşap yapı elemanlarının birleştirilmesi yöntemleriyle birleştirilebilir. Samanlık yapılarında çatılarda oluşan fazla yük kaldırılarak daha hafif bir malzeme kullanılabilir. Yeni yapılar söz konusu olduğunda ise yerel kimliğin korunmasına dikkat edilerek ve oranın doğal malzemesinin kullanımı ile birlikte yaşam kalitesi düşünülerek tasarımlar yapılmalıdır. Kırsal mimarinin sürekliliği için yapılara modern yaşamın gerekliliği olan 1sıtma, elektrik ve mekanik gibi tesisatların ilave edilmesi gerekmektedir. Hisarözü köyü bu disiplinler arası çalışmaların uygulanabileceği önemli bir kırsal alan olarak karşımıza çıkmaktadır. Yapılaşmanın kimliğini bozmadan mekân kurgusuna gidilmeli ve süreklilik sağlanmalıdır.

Geleneksel dokunun korunarak geleceğe aktarılması kırsal mirasın sürdürülebilirliği açısından büyük önem taşımaktadır. Hisarözü Köyü kırsal alanı, fiziki yapı ve tarihsel süreç içerisinde bütünlüğünü bozmamıştır. Göçün ana kaynağı olan ekonomik durum çözüldügünnde dokuda yaşamın devam edeceği düşünülmektedir. Ekonomik durumun çözümle- 
mesi yapılırken sosyo-kültürel etki gözetilmelidir. Toplumun kültürel yapısına uygun olarak kalkınma çalışmalarına gidilmeli ve bu çalışmalarda yerel halkın yaşam konforu gözetilerek kapsamlı çalışmalar yapılmalıdır. $\mathrm{Bu}$ çalışmalarda, yerel yönetim desteğiyle yeni teknolojiler kullanılarak organik tarım uygulaması yapılabilir ve bu konuda halk bilinçlendirilerek pazarlamanın birinci elden satışı sağlanarak çözümlemelere gidilebilir.

Değişen dünyadaki hızlı ekonomik ve teknolojik gelişmeler göz önünde bulundurulduğunda Hasarözü Köyü'nde tespit edilen, insan ölçeğinde yere ve doğaya bağlı yaşamın oluşturduğu mimari mirasın değerleri öne çıkmaktadır. Güncel yapım teknikleri ile yeni yapıların oluşturulması, ekonomik sürekliliğin sağlanamaması, kullanıcılardaki mimari miras farkındalığının oluşturulması, genç nüfusun ayrılması ve teknik donatıların geleneksel mimari miras ile bütünleşmesi gibi sorunsallar bu makalede tespit edilmiştir. Hisarözü Köyü'ndeki mimari mirasa olan yaklaşımlar, katılımcı koruma yöntemleri ile belirlenmelidir.

Kırsal mirasın sürdürülebilirliği üzerine doğru planlamalar yapıldığında korumanın sürekliliği gelişme gösterilebilir. Varlıklarını sürdürmeye çalışan kırsal alanlar kapsamında; devlet, yaşayanların oluşturduğu kooperatifler, sivil toplum örgütleri, belediye, alanında uzman kişiler tarafından ortak bir çalışma yürütülerek verimli sonuçlar elde edilecektir. 


\section{Extended Abstract}

\section{A Research on the Continuity of Rural Heritage: The Case of Hisarözü Village}

\author{
Derya Gümüş \\ Kocaeli University
}

\author{
Emre Kishalı \\ Kocaeli University
}

In the second half of 20th century, the vernacular architecture, also called architecture without architects were studied under various disciplines such as sociology, architecture, anthropology, engineering, city planning etc. Turkey which host various rural areas has been exposed to transformations due to the legislation, urban policy, industrialization, modern technology and globalization. Problematics of sustainability on rural heritage in Marmara Region were discussed, due to the fact that the area is located in the most populated and industrialized area of Turkey.

In this context, the village of Hisarözü in Göynük located in the town of Bolu Province was analyzed. The rural area was selected as a case study in the context of the sustainability and conservation. The literature review was conducted for the area; however, insufficient data was obtained related to the architectural properties of the village. Therefore, the inventory studies were done for revealing the existing architectural heritage. Later, direct investigation and photography on the existing buildings in the urban fabric, interviews with the inhabitants and the analysis of rural areas were carried out during the field visits. The current conditions of physical properties of area and the social analysis show that the rural properties of the village were not lost and the original character of architecture heritage substantially preserved.

On the other hand demographic analysis considering the number of users, the age of population and the migration facts were researched, it is observed that the number of inhabitants is few. The reflection of this parameter on the architectural heritage indicate that the structural safety of 
the buildings is good but most of them are obsolete due to the socio-cultural effects such as migration to larger settlements, multi shareholdings, and energy saving issues. Moreover, it is deduced that all storehouse buildings are vacant whereas the some of the haylofts are still being used by the inhabitants working on the husbandry.

In the research there are four phases in the methodology. In the first part, the rural architecture, heritage, and conservation were discussed. The national and international studies were reviewed and different definitions were presented. The aim is to compare the architectural values with the experts working on this subject. The state of art on rural heritage, its conservation and the historical development of Göynük is rich. In the second part, the historical development, physical, social, economic properties and rural architecture of Göynük which is retained between the urban-rural interfaces were explained. Specifically Hisarözü Village were examined. The historical development, geographic and socio economic properties of Göynük was introduced mainly and its influences on Hisarözü were sought.

Later, the conservation and sustainability problems of the rural architecture in the village were addressed. In this part, the essential study is to understand the urban fabric in terms of qualitative and quantitative perceptions. The number of building representing rural heritage and the new buildings was detected in three different neighborhoods of Hisarözü. Then the physical properties, the use value and structural safety were investigated by the direct investigations and documentations located in Merkez (Central) Neighbourhood, Şabanlar Neighborhood and Hapşanlar Neighbourhood. It is revealed that, the percentage of traditional building in all urban fabric structures are very high. It is found that $88 \%, 94 \%$ and $91.5 \%$ of total buildings are vernacular architecture examples in Merkez, Şabanlar and Hapşanlar neighbourhood respectively. The functions of the vernacular architectures can be listed as housings, haylofts, storehouses, barns, hencoops, school and mosques. In the area, the structures are evaluated as good condition if there the damage and cracks were not noticed during the investigations. When partial degradations, damages and interventions were found the safety level was considered as medium. The ruins and partial destructions were evaluated as bad conditions for the buildings. The percentage of structural safety located in the whole villages are $68 \%, 22,5 \%$ and $9,5 \%$ as good, medium and bad respectively. 
Finally, the suggestions on conserving and sustaining the rural architecture were suggested considering the town of Hisarözü. The civil architecture buildings need to be conserved in a holistic way. The physical tissue of rural area has gone through various developments. The multi shareholding, heating problems, migration and socio-economic reasons lead to abandonment of the buildings. The tendency of the inhabitants is to construct new buildings and/or leave the vernacular structures. Moreover, the necessity of increasing awareness towards cultural heritage, the sustainability of economic developments with new organic agriculture and ecological productions is raised. The farms in the villages are very productive agricultural lands. Distribution and share of the products obtained from the current cultivated areas by agricultural cooperatives can be provided. In building scale, the cracks and degradations need to be intervened in order to provide substantial conservation.

On the other hand, it is inevitable to adapt the technological equipment in terms of heating, electricity, mechanical equipment to the vernacular architecture examples. The technical adaptation to the rural architecture with the multi-disciplinary approach was highlighted. Therefore, the living heritage in the rural area is desired and it can be achieved by the participative approaches of all stakeholders like municipalities, cooperative of inhabitants, academics, experts and state supports funding.

\section{Kaynakça/References}

Ahunbay, Z. (2017). Tarihi çevre koruma ve restorasyon. İstanbul: Yem Yayınları.

Akcan, R. (1967). Göynük'ün beşeri ve iktisadi tetkiki. Yayınlanmamış Lisansüstü Tezi. İstanbul Üniversitesi, İstanbul.

Aktaş Yasa, A. (2013). Kültürel zenginlikleri ile Göynük. A. Aktaş Yasa ve A. Soysaldı (ed.), Göynük el sanatları paneli ve çalıştayı bildirileri, 2, 17-46. Ankara: Göynük Belediyesi Yayını.

Akurgal, E. (1998). Anadolu kültür tarihi. Ankara: Tübitak Yayınları.

Anonim (1998). Tarihin, yolların ve yeşilliğin buluştuğu Göynük. Göynük Kaymakamlığı Köylere Hizmet Götürme Birliği Yayınları 1, Göynük.

Aran, K. (2000). Barınaktan öte: Anadolu kır yapıları. Ankara: Tepe Mimarlık Kültürü Merkezi. 
Aslantürk, İ. H. (2007). 16. yüzyılda Yenişehir, Yarhisar ve Göynük nahiyeleri (Tahrir defterlerine göre). Master Tezi. Gazi Üniversitesi, Sosyal Bilimler Enstitüsü, Ankara.

Başbakanlık Osmanlı Arşivi, Tapu Tahrir Defteri, Nr.453

Bektaş, C. (2001). Halk yapı sanatı. İstanbul: Literatür Yayıncılık.

Bolu İl Yillı̆̆ı. (1973). İstanbul.

Brower, S. (1988). Design in Familiar Places. New York: Praeger.

Brower, S. (1989). Residents' and outsiders' perceptions of the enviroliment. S. M. Low and E. Chambers (der.), Housing, Culture and Design, Philadelphia: University of Pennsylvania Press.

Dikmen, Ç. B. ve Toruk, F. (2015). Geleneksel Göynük evlerinin mekânsal yapısı ve koruma önerileri. C. Demir, E. Pelit, ve S. Kaya (ed.), Afyon Kocatepe Üniversitesi Sosyal Bilimler Dergisi, 17(1), 99-128.

Eldem, S. H. (1954). Türk evi plan tipleri. İstanbul: İTÜ Mimarlık Fakültesi Yayınları.

Erdem, A. (1996). Göynük tarihsel siti, dini ve sivil mimarlı örnekleri, koruma sorunları ve yeni yapılanma koşulları. Doktora Tezi. Yıldız Teknik Üniversitesi, Fen Bilimleri Enstitüsü, İstanbul.

Eres, Z. (2008). Türkiye'de planlı kırsal yerleşmelerin tarihsel gelişimi ve Erken Cumhuriyet Dönemi planlı kırsal mimarisinin korunması sorunu. Doktora Tezi. İstanbul Teknik Üniversitesi, Fen Bilimleri Enstitüsü, İstanbul.

Eres, Z. (2013). Türkiye'de geleneksel kırsal mimarinin korunması: Tarihsel süreç, yasal boyut. K.K. Eyüpgiller ve Z. Eres (yay.), Prof.Dr. Nur Akın'a Armă̆an Mimari ve Kentsel Koruma, 457-469. İstanbul: YEM Yayınları.

Eres, Z. (2016). Türkiye' de geleneksel köy mimarisini koruma olasılıkları. Ege Mimarlı Dergisi, 2016/01, 8-13.

Evliya Çelebi (1975). Evliya Çelebi seyahatnamesi C.1-2. İstanbul: Üçdal Neşriyat. Göynük Belediyesi Arşivi.

Günal Öden, Z. (1999). Umuroğulları hakkında bazı görüşler. XII. Türk Tarih Kongresi, 2, Ankara: Türk Tarih Kurumu.

İbn-i Batuta (H.1330). Seyahatname-i İbn-i Batuta C.1. İstanbul: Matba-i Amire.

ICOMOS, (2017). ICOMOS-IFLA principles concerning rural landscapes as heritage. International Council of Monuments and Sites (ICOMOS).

İşcanı, B. (2016). Muğla-Datça Hızırşah Köyü kırsal sit alanı koruma projesi. Yüksek Lisans Tezi. İstanbul Teknik Üniversitesi, Fen Bilimleri Enstitüsü, İstanbul.

Kılıç Benzer, A. N. (2006). Bolu-Göynük ve yakın çevresi doğal ve kültürel kaynaklarının ekoturizm açısından değerlendirilmesi. Doktora Tezi. Ankara Üniversitesi, Fen Bilimleri Enstitüsü, Ankara.

Köksal, T. G. ve Kishalı E. (2012). Vernacular architecture in Gölcük and sustainable solutions for its conservation. International Seminar on Vernacular Settlements. 
Köksal, T. G. ve Kishalı E. (2014). Kartepe: Mimari doku - mimari miras. Kartepe Kitabı, 2, 639-684.

Kuban, D. (2001). Türkiye'de kentsel koruma, kent tarihleri ve koruma yöntemleri, İstanbul: Tarih Vakfı Yurt Yayınları.

Kut Görgün, E. ve Yörür N. (2018). Kırsal yerleşmelerde özgün dokunun korunmasında bir araç olarak köy tasarım rehberleri: Ödemiş bademli örneği. TÜBA-KED, 2018/17, 25-46.

Mazlum, D., Eres, Z., Barlık, T., ve Türk, Ş. (2005). Orhangazi (Bursa) Karsak Köyü kırsal mimarlık envanteri. TÜBA-KED, 2004/3, 229-258.

Oliver, P. (1997). The encyclopedia of vernacular architecture of the world, Cambridge University Press.

Oliver, P. (1998). Encyclopedia of vernacular architecture of the world 1. Cambridge: Cambridge University Press.

Oliver, P. (2002). Gereksinim ve süreklilik. Çeviri: T. Selin Tağmat, Mimarlık Dergisi, 304, s. 33-34

Rapoport, A. (2002). Geleneksel çevreler, kültür ve koruma. Çeviri: Selcen Tuncer, Mimarlik Dergisi, 304, s. 27-32.

Scazzosi, L. (2018). Landscapes as systems of tangible and intangible relationships. Small theoretical and methodological introduction to read and evaluate Rural Landscape as Heritage. E. Rosina \& L. Scazzosi (Der.), Tthe conservation and enhancement of bult and landscape heritage a new life for the ghost village of mondonico on lake como içinde (ss. 19-41). Milano, İtalya: Poliscript politecnino di Milano.

Soysal, M. (1998). Köy Sosyolojisi. Çukurova Üniversitesi Ziraat Fakültesi Ders Kitapları Yayın, A-66, Genel Yayın, 211, Adana.

Şayın, G. (2016). Denizli Hisarköy (Attuda) kırsal mimari mirasının doku analizi ve koruma sorunları. Yüksek Lisans Tezi. Dokuz Eylül Üniversitesi, Fen Bilimleri Enstitüsü, İzmir.

Toprakeşenler, S. (1994). XVI. yüzyılda Göynük ve Yenice-i Taraklı kazaları. Yüksek Lisans Tezi. Anadolu Üniversitesi, Sosyal Bilimler Enstitüsü, Eskişehir.

Yurt Ansiklopedisi (1982). Bolu C.2, İstanbul: Anadolu Yayıncılık.

Derya Gümüş, 1994 yılında Bolu'da doğdu. İlk, orta ve lise eğitimini Bolu'da tamamladı. 2017 yılında Mimar Sinan Güzel Sanatlar Üniversitesi Mimarlık Bölümü'nden mezun oldu. Yüksek lisans eğitimine Kocaeli Üniversitesi, Fen Bilimleri Enstitüsü, Mimarlık Bölümü ABD.'nda devam etmektedir.

Was Born in 1994 in Bolu. Completed primary, secondary and high school in Bolu. Graduated from Department of Architecture, Mimar Sinan Fine Arts University. Still pursuing the Master of Science degree in the Architecture programme of Kocaeli University.

E-mail: dgumus1434@gmail.com 


\section{Emre Kishalı}

Orta Doğu Teknik Üniversitesi İnşaat Mühendisliği Bölümü'nden Ocak 2005 tarihinde mezun olduktan sonra İtalya, Politecnico di Milano Lecco yerleşkesinde Mimari Mühendislik alanında yüksek lisans ve yine aynı üniversite Milano yerleşkesinde Restorasyon alanında doktora yapmıştır. 2012 yılından itibaren Kocaeli Üniversitesi Mimarlık Bölümü Restorasyon ABD. 'da öğretim üyesi olarak görev yapmaktadır. Çalışma alanları mimari mirasın korunması ve sürdürülebilirliği, iyileştirme - güçlendirme, hasarsız testler, ahşap yapılar ve tarihi yapıların planlı korunmasıdır.

Received his B.S. from Middle East Technical University, Department of Civil Engineering (2005). Earned his master's degree (2007) on Architectural Engineering programme of Politecnico di Milano and PhD (2011) degree on Restoration field in the Building Engineering programme at Politecnico di Milano. Currently works as an assistant professor at Kocaeli University Faculty of Architecture and Design since 2012. Major research areas are sustainability and conservation of architectural heritage, consolidation - strengthening, non-destructive tests, and timber buildings and planned conservation of historic buildings.

E-mail: emre.kishali@kocaeli.edu.tr

\section{Kaynakça Bilgisi / Citation Information}

Gümüş, D. ve Kishalı, E. (2018). Kırsal Mirasın Sürekliliği Üzerine Bir İnceleme: Göynük Hisarözü Köyü Örneği. IDEALKENT - Kent Araştırmaları Dergisi, 25, 909-940. 